\title{
The Political Evolution of Class and Religion
}

An Interpretation for the Netherlands, 1971-2006

\section{Nan Dirk de Graaf}

\section{Giedo Jansen}

\section{Ariana Need}

DOI:10.1093/acprof:oso/9780199663996.003.0009

\section{Abstract and Keywords}

This chapter investigates whether changes in religious and class voting in the Netherlands can be interpreted by social and political factors. From the social perspective we focus on compositional changes, education, changes in the class structure, and religious integration. From the political perspective we examine the impact of merging political parties and changes in party positions. Employing Eection Surveys (1971-2006) and Manifesto-data, reveals that the rise of the class of socialcultural specialists is important for understanding changes in the class-vote relationship. Although party positions are relevant they do little to explain the decline in class-based voting. Weakening religious integration largely explains the decline of political boundaries between non-religious voters and Catholics and Calvinists. After taking party positions into account the effect of the CDA-merger no longer reduced religious based voting, suggesting that the merger resulted in a revised ideological choice set facing voters. Furthermore, religious voting increases when traditional moral issues in manifestos are emphasized.

Keywords: religious voting, secularization, class voting, social change, political change, party positions, voting behaviour, electoral change, netherlands

\section{Introduction}

Religion and to a lesser extent class have been the dominant political divisions within the Netherlands for a long time. Religious people were always more likely to vote for a religious party and labourers were al ways more likely to vote for classical left-wing parties. Research shows that class-based voting and religious-based voting has declined (De Graaf 1996; Irwin and Van Holsteyn 2008; Need 1997; Nieuwbeerta and De Graaf 1999; Van der Kolk 2000). Although there is speculation about the causes of these trends there is not much research that systematically tries to explain trends in cleavage-based political preferences. Our ambition is to investigate how variations in these associations over time can be explained by macro-level developments, changing ideologies, and party positions. More specifically, building on earlier work on cleavage voting in the Netherlands (De Graaf, Heath, and Need 2001), we aim to answer the question of how socio-economic development and party strategy interact to produce changes in the social bases of political choice in the Netherlands.

In this chapter we first describe social changes that are relevant for understanding the developments in the political cleavage structure of Dutch society since 1971. Next we introduce the theoretical basis of our hypotheses. Like all other chapters in this book we distinguish between the bottom-up and the topdown approach. The bottom-up approach uses social changes as a source for changes in political choices, while the top-down approach uses changes in party positions. From the top-down or 'political choice' perspective patterns in cleavage voting reflect the outcomes of party behaviour rather than (p.206) bottom-up compositional changes in the social structure of society. We integrate these two approaches in a single model. The hypotheses are tested using the integrated Dutch Parliamentary Bection Studies (DPES) between 1971 and 2006, supplemented with data on the manifestos of Dutch political parties. 


\section{Changes in the Class and Religious Structure of the Netherlands}

The occupational and religious structure of the Netherlands has changed considerably in the past four decades. With respect to the occupational structure we have seen a contracting working class and an expanding service class. The manual class has shrunk from more than 40 per cent in 1970 to less than 30 per cent in 2004 (Güveli 2006). To understand class voting, the simple distinction between blue and white collar classes no longer suffices (cf. Nieuwbeerta 1995). Nieuwbeerta's (1995) comparative study utilized the Erikson, Goldthorpe, Portocarrero (EGP) class schema and distinguished the unskilled manual class, the skilled manual class, the petty bourgeoisie, the routine non-manual class, and the lower and upper service classes. However, more recent research shows that due to changes in employment patterns and class structure even this more elaborate class distinction needs improvement. In the Netherlands, the majority of the employed male population works in the high and low service classes. These are the high- and low-grade professionals and managers, known as classes I and II of the EGP class schema (Ganzeboom and Luijkx 2004). When combined these two service classes increased in size from 31 per cent in 1970 to more than 50 per cent in 2004 (Güveli 2006). Güveli and De Graaf (2007) and Güveli, Need, and De Graaf (2007a, 2007b) argue that in postindustrial societies, two extra sub-classes should be distinguished within the service classes, namely: the social-cultural specialists (e.g. social workers, teachers, lawyers) and the technocrats (e.g. engineers, accountants, and office managers). Construct and criterion validation tests (Güveli 2006) support these new class distinctions. Even after taking level and field of education into account these new distinctions help to account for political choices (Van de Werfhorst and De Graaf 2004). The identification of distinct political preferences among a class of social-cultural specialists within the service class might therefore partly explain apparent declines in class voting observed when using less differentiated measures of EGP class position. We therefore apply the adjusted schema in this chapter.

Figure 9.1 a reports the percentage of social-cultural specialists and technocrats in the labour force. It confirms that the service class in the Netherlands has expanded a great deal (De Graaf and Steijn 1997) and that this (p.207)

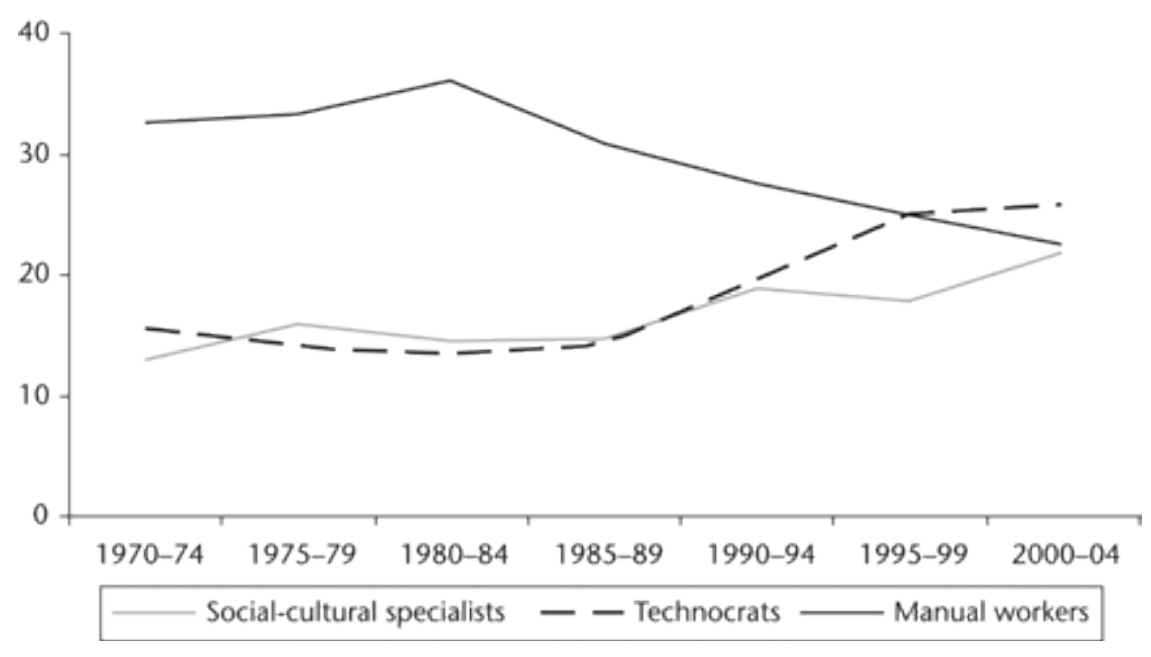

Figure 9.1a. Trends in the percentage of social-cultural specialists and technocrats in the labour force between 1980 and 2004.

Source: Güveli (2006: 52). 


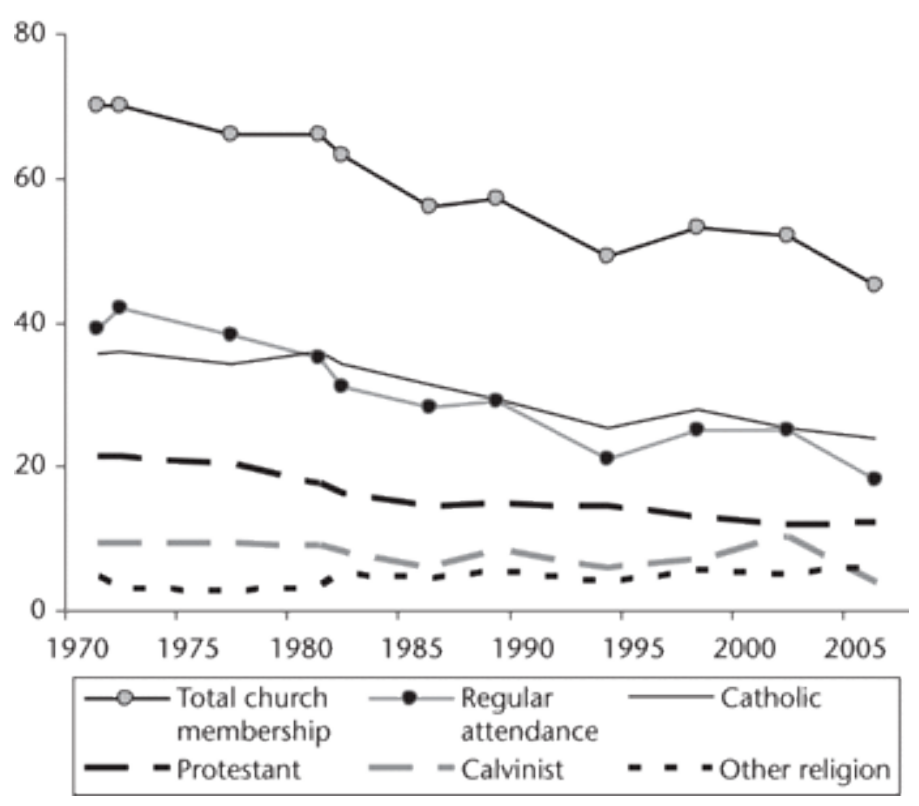

Figure 9.1b. Trend in church membership, church attendance, and denomination in percentages between 1971 and 2006.

\section{Source: DPES 1971-2006.}

(p.208) increase applies to both the social-cultural specialists and the technocrats. As a consequence the relative size of the manual class has declined considerably.

Similarly, as shown in Figure $\underline{9.1 \mathrm{~b}}$, the religious proportion of the electorate has fallen substantially. The religious cleavage in the Netherlands is at least two-dimensional, comprising the contrast between Protestants and Catholics as well as the contrast between the religious and non-religious population. However, due to the wide variety of Protestant groups in the Netherlands (Janse 1985) we distinguish Protestants affiliated with the Dutch Reformed Church and Protestant Church from those who belong to more orthodox Calvinist churches. Figure $\underline{9.1 \mathrm{~b}}$ reveals a more or less linear downward trend of both church attendance and church membership over a period of thirty-five years. Church membership has dropped from 70 per cent to 45 per cent and regular church attendance (i.e. at least once a month) has dropped from 39 per cent to 18 per cent. Using different data De Graaf and Te Grotenhuis (2008) showed that traditional religious belief and belief in the supernatural also declined. Figure $9.1 \mathrm{~b}$ shows that the decline in religious affiliation runs more or less parallel for Catholics and Protestants, dropping from 37 per cent and 23 per cent membership in 1971 to 24 percent and 12 per cent in 2006, respectively. The Calvinist group proved to be most stable over the same period with a total membership of around 10 per cent.

\section{Bottom-up: Compositional Changes and the Blurring of Group Boundaries}

Changes in the sizes of different class or religious categories can be defined as compositional changes. When cleavage voting is measured in (log) odds ratios (as in the present case) compositional changes do not necessarily affect the strength of the association because the odds ratio is invariant to the marginal totals. We therefore need to distinguish compositional changes from the blurring of cleavage boundaries (De Graaf, Heath, and Need 2001). On the one hand, as we will argue later, compositional changes such as the shrinking size of the manual class or religious population are likely to affect the relevance of class- or religion-specific issues at the party level if, according to a Downsian model, parties change their position in order to maximize the number of voters (cf. Evans 2000). For example, the trends reported in Figure $\underline{9.1 \mathrm{~b}}$ imply that the decline in the relative number of church members will cause compositional effects of religion on voting, because religious parties (assuming that the association between religiosity and vote remains stable) have fewer potential supporters. On the other hand, as argued in the introductory chapter of this book, the process of blurring boundaries will result 
in less distinctive denominational groups, both culturally and socially. This will (p.209) ultimately lead to a convergence in their political preferences. We therefore expect to find that:

$\mathbf{H 1 a}$ and $\mathbf{b}$ : The association between denomination $(\mathrm{H} 1 \mathrm{a}) / \mathrm{class}(\mathrm{H} 1 \mathrm{~b})$ and party choice generally becomes weaker.

Our intention is to test these processes of class and religious dealignment more extensively than in De Graaf, Heath and Need (2001) by examining the ideology of group-members over time. This way we can not only investigate associations between group membership and voting but also the intervening effect of ideology. This is of theoretical importance since it will aid our understanding of the association between cleavages and vote changes. Traditional class voting is concerned with less privileged classes that support leftist parties because they stand for greater socio-economic equality. More privileged classes have less interest in redistributionist policies, and can be expected to be more economically conservative. We expect that as the ideological differences on redistribution between classes become smaller, the class basis of voting diminishes. Therefore we expect to find that the changing association between class and vote can be explained by economic conservatism. ${ }^{-1}$ The ideology that connects religion and vote is cultural conservatism (Middendorp 1991). Church attendees are culturally more conservative than non-attendees (Felling and Peters 1986). Conservative religious values cause church attendees to vote for parties that stand for traditional moral values, which in the Netherlands are usually the confessional parties. A decline in the religion-vote relationship should therefore also show up in a weaker religious integration, as indicated by a decline in the association between denomination and church attendance. Since we lack indicators for cultural conservatism in our data we will use church attendance instead. Therefore we expect both the association between class and economic conservatism, and the association between having a denomination and church attendance, to go down. We also expect an intervening effect of the ideologies between class/denomination and party choice that might interpret the decline in cleavage based voting. We therefore hypothesize:

$\mathbf{H} 2 \mathbf{a}$ and $\mathbf{b}$ The decline in the association between denomination $(\mathrm{H} 2 \mathrm{a}) / \mathrm{class}(\mathrm{H} 2 \mathrm{~b})$ and party choice becomes weaker when we take church attendance $(\mathrm{H} 2 \mathrm{a}) /$ economic conservatism $(\mathrm{H} 2 \mathrm{~b})$ into account.

$\mathbf{H} 2 \mathbf{c}$ and $\mathbf{d}$ The association between denomination and church attendance $(\mathrm{H} 2 \mathrm{c})$ and between class and economic conservatism $(\mathrm{H} 2 \mathrm{~d})$ generally becomes weaker.

\section{Top-down Changes: Merging of Political Parties and Shifting Manifestos}

The political choice model has a top-down perspective. It focuses on how political parties take different positions along the two distinguished ideologies. From a top-down perspective cleavage voting is conditioned by the extent to which parties are associated with social classes or religious groups rather than by the strength of the traditional divisions in society (Oskarson 2005). In this case the agent of change is political, rather than sociological. Though strategic movements in party positions are themselves assumed to be conditioned by changes in social structure, such as the decline in the size of the working class and levels of religious participation, social demographic conditions alone are not sufficient to explain party behaviour (Kitschelt 1994).

We distinguish between two types of top-down political changes. First, we discuss changes in the ideological positions of parties. Second, we discuss the evolution of the Dutch party system with regard to the availability of confessional parties as well as left-wing parties. As we discuss later, the Christian Democratic Party in the Netherlands was formed in the late 1970s after the merger of three denominational parties, each with a distinguished prior history. A second notable political merger in the Netherlands was the amal gamation of four minor left-wing progressive parties into the GreenLeft Party in 1989. 
According to the political choice model the extent to which individual ideology is related to voting depends on the ideological positions of parties. A person with a progressive economic ideology is more likely to vote for a party that makes clear economic left-wing statements. On the basis of a Downsian model-stating that parties change their position in order to maximize the number of voters - we expect that the parties will move towards the centre. Keman and Pennings (2006) have indeed shown a convergence of political choices. Many Social Democratic as well as Christian Democratic parties in Western Europe, including those in the Netherlands, moved to the centre during the 1990s. Labour parties did so because the relative size of the manual class is shrinking, and religious political parties moved towards the centre because of the shrinking relative size of the religious group. Hence, the political choice approach predicts that as a result of ideological political convergence of parties, social cleavages will lose their power to predict party choice.

(p.211) $\mathbf{H 3 a}$ and $\mathbf{b}$ The decline in the association between denomination $(\mathrm{H} 3 \mathrm{a}) / \mathrm{class}(\mathrm{H} 3 \mathrm{~b})$ on the one hand and party choice on the other is less strong when we take the ideological position of parties into account.

However, given our focus on ideologies we expect that the convergence of the manifestos will weaken the relevance of ideologies. We therefore hypothesize:

$\mathbf{H} 4 \mathbf{a}$ and $\mathbf{b}$ The decline in the association between church attendance $(\mathrm{H} 4 \mathrm{a}) /$ economic conservative ideology $(\mathrm{H} 4 \mathrm{~b})$ on the one hand and party choice on the other becomes less strong when we take the position of parties into account.

\section{Description of Parties and Political Changes}

In the period 1971-2006 the average number of parties represented in the Dutch Parliament was about eleven with a maximum of fourteen. The number of parties that appear on the ballot each election is even larger. In order to provide a parsimonious study that allows a comparison over time, it is necessary to group parties into a limited number of party families. Although there are several parties that have won seats at one or more elections, we can in practice distinguish four major groupings which have had a more or less continuous existence. We label these groups: (1) old left (PvdA, DS70, CPN, SP), (2) confessional (CDA, KVP, ARP, CHU, RKNP, RPF, GVP, CU, SGP), (3) free-market liberal(VVD, BP, NMP), and (4) new left (D66, GroenLinks, PPR, PSP, EVP).

The first three groups follow a fairly conventional classification of party families (e.g. Lane and Ersson 1999; Knutsen 2004). Within the old left we collapse the socialist and communist party families. The new left group is a combination of the liberal reformist party D66 and GreenLeft. Despite substantial differences on economic issues the latter parties are grouped together because of their joint emphasis on a political agenda cross-cutting the traditional right-left dimension. It has been stressed by Kitschelt (1993) that Green parties are often related to broader left-libertarian values rather than a single focus on environmentalist issues.

We do not include a separate party group of far and new right parties, in order to examine whether the working class has abandoned the left to the advantage of the 'new right'. In the Netherlands such a choice does not yield a comparable category suitable for over-time analyses. The List Pim Fortuyn (LPF), for example, attracted 17 per cent of the voters in 2002 and 5.6 per cent in 2003 (Van Holsteyn, Irwin, and Den Ridder 2003) but quickly collapsed afterwards. Before the rise and fall of the LPF new and far right voting was a relatively minor phenomenon in Dutch politics; the extreme right Centre Democrats (CD) only gained 0.9 per cent and 2.4 per cent of the votes in the 1989 and 1994 elections, respectively. In 2006 the Party for (p.212) Freedom (PVV) managed to draw support on an antiestablishment agenda against immigration and 'islamization' (5.9 per cent in 2006 and even 15.4 per cent in 2010). Although the success of the PVV was accompanied by heavy losses for the PvdA and of course the idea of cultural voters pops up immediately, it is too early to examine whether the emergence of the PVV has a long-standing impact on the relationship between the working class and 
the classical left and we should realize that in this chapter the 2006 election is the latest one for which we have data - future research should reveal whether the PVV will have a more lasting impact.

The first group of parties, the old left, is dominated by the PvdA. This is a typical European socialist party, relatively strong in the working class, analogous to the SPD in Germany and the Labour Party in Britain. The PvdA has been a major political force throughout the period 1971-2006. We also include in the old left group two small parties (DS70 and the SP) which have had little electoral strength between 1970 and 2006 (DS70 contending elections only from 1971 to 1982; Mackie and Rose 1991: 325), but which also drew on the working class for support. In addition, we include the Communist Party (CPN) until the 1986 elections, although this party merged with GreenLeft from the 1989 elections onwards. The reason is that the CPN is best understood as belonging to the old left, being a working-class party, until the 1986 elections.

Our second group of political parties consists of the religious or confessional right. Historically there had been three main religious parties: the KVP, which drew its support mainly from Catholics: the ARP, popular among members of the Calvinist churches and other orthodox Protestants, and the CHU, which drew its support mainly from members of the liberal Protestant churches. These parties are considered to occupy a centre-right position. These three religious parties participated in the 1977 election on a common slate and in 1980 they formally merged into the CDA. Ever since the introduction of universal suffrage at least one of these Christian democratic parties has been part of the governing coalition, although this sequence was finally broken in 1994. We should note that there are other confessional right-wing parties (SGP, GPV, RPF, and RKPN) which did not join the CDA. However, two of these parties (the protestant parties GPV and RPF) merged into the Christian-Union from the 2002 elections onwards. These parties are much more conservative than the three main confessional parties (drawing votes mainly from Calvinists and orthodox Protestants) and receive much less support overall. There was little change in their support after the formation of the CDA. Interestingly, however, the Christian Union takes a more leftist position than the CDA on economic issues and the label 'minor right' (kleinrechts) that was used to summarize the CU predecessors no longer applies (Pellikaan 2002).

(p.213) Our third group consists of the free-market or liberal right. This group contains the VVD, the BP (farmers party), and the NMP (Middle Class Party). The BP participated in the elections from 1959 up to 1977, although with little success. The NMP only contested elections during the 1970s. Both were right-wing parties. The main secular right-wing party, however, has been the liberal (conservative) VVD. It has usually been the main 'third force' in Dutch politics, getting a substantial share of the vote but usually running well behind the PvdA and the CDA. It has often been a coalition partner of the Christian Democrats.

The new left group consists of various small political parties. First, the 'new' left was represented by D66 which as its name, Democrats 1966, implies was formed in 1966 on a platform of constitutional reform. It has contested all elections since then, although with varying fortunes. During the 1967 elections D66 had a more left-wing position, but the party made a shift towards the political centre after it contested the 1972 election by adopting a joint party programme with the PvdA and the PPR (Krouwel 1995: 175). Nonetheless D66 has evolved into a leftist/liberal party (Van der Ejk and Niemöller 1983: 7) with a continuing concern for constitutional issues, not unlike the Liberal Democrats in Britain. It has been part of coalition governments that have al so included the PvdA. Since D66 came into existence before the first available election survey we cannot test whether the rise of this party affected the importance of class cleavages for voting behaviour. Second, we include GreenLeft and its progressive predecessors (PPR, PSP) with the new left parties. GreenLeft was effectively formed in 1989 when four radical parties fought the election with a common party list. These four parties were the CPN (Communist Party), the PSP (Pacifist Socialist Party), the PPR (Radical Party) and the EVP (Evangelical People Party). These four parties had quite diverse and evolving histories, the CPN dating from 1936, the PSP from 1959, the PPR from 1971, and the EVP from 1981. Their electoral strength has always been weak and they have not usually, either before or after 1989 , been in government. 


\section{Hypotheses about the Consequences of Merging Political Parties}

Our hypotheses about the effect of political restructuring take a different form than does the sociological hypothesis of general and gradual class and religious dealignment. We expect to find that, if political options have had any autonomous effect, the changes in the relationship between social position and vote will be more time-specific and more group-specific. Thus we look for (a) changes in the association between religion and vote after the formation of the common Christian Democrat party list in 1977 and the formation of the (p.214) ChristianUnion in 2002, and for (b) changes in the association between class and vote after the formation of the common GreenLeft party list in 1989.

More specifically we postulate that the new CDA is less attractive to the specific religious denominations than the individual parties had been before. At the same time, the CDA is more attractive to non-religious people since it is no longer or, at least, is less strongly associated with specific sectarian connotations. Consequently, the association between religion and vote will go down. This is a specific realignment rather than a general dealignment, since there is no reason to suppose that the formation of the CDA would affect the choices of religious people between say the old left and the new left. Second, we look for changes in the religion-vote association after the formation of the ChristianUnion. Although we have less clear expectations about this merger, we expect that the new CU will appeal less to some orthodox Protestants partly because the party name no longer contains an explicit reference to either Protestantism or the Reformation. A denominationneutral name and more left-leaning profile may also have made the party more attractive to nonProtestants. Although the vote share of the $\mathrm{CU}$ and its predecessors has al ways been small we expect the association between religion and vote for religious versus non-religious parties to go down as a result of the party merger. Our hypothesis is:

H5 The association between denomination and vote for religious versus non-religious parties shows an abrupt decline after the 1977 election when the CDA came into existence $(\mathrm{H} 5 \mathrm{a})$ and after the 2002 election when the $\mathrm{CU}$ came into existence $(\mathrm{H} 5 \mathrm{~b})$.

With respect to elections after the formation of the GreenLeft party list in 1989 one hypothesis can be put forward. It is likely that the social-cultural specialists switched to the GreenLeft (part of the new left) once the new party list was established. Hence:

H6 The odds of the social-cultural specialists supporting new left parties increase after the formation of the GreenLeft.

\section{Data and Variable Construction}

To test our hypotheses we use data from the Dutch Parliamentary Bection Studies (DPES) covering the general elections 1971-2006. We use information on social class (based on detailed occupational information) religion, economic ideology, church attendance, party choice, and social background characteristics from eleven election surveys (1971 [ $\mathrm{N}=2.495], 1972$ [ $\mathrm{N}=1.526], 1977$ [ $\mathrm{N}=1.856]$, 1981 [ $\mathrm{N}=2.305], 1982$ [ $\mathrm{N}=1.541], 1986$ [ $\mathrm{N}=$ (p.215) 1.630], 1989 [ $\mathrm{N}=1.745], 1994$ [ $\mathrm{N}=1.812]$, 1998 [ $\mathrm{N}=2.101], 2002$ [ $\mathrm{N}=1.574]$, and 2006 [ $\mathrm{N}=2.623])$. We excluded the 2003 survey because that survey lacks detailed occupational information.

Social class: We use the modified EGP class schema taking the social-cultural specialists as a separate class from the technocrats. Despite their middle-class position, social-cultural specialists are relatively left-wing (De Graaf et al. 2001), a political distinctiveness that has crystallized over the last thirty years (Güveli, Need, and De Graaf 2007a; see 〈http://www.ayseguveli.nl.sci-hub.bz/research.aspx〉 for recoding ISCO-scores into the new classes). To get the most reliable class measure we used the fourdigit occupational codings of the Central Bureau of Statistics. For the 1989, 1994, and 2006 surveys we had to use the original codings only available at the Central Bureau of Statistics in Heerlen. ${ }^{2}$ Ultimately we obtained the following classes: (1a) higher technocrats; (1b) higher social-cultural specialists; (2a) lower technocrats; (2b) lower social-cultural specialists; (3) routine non-manuals; (4) 
self-employed; (5) manual class. We collapsed the higher manual and lower manual class, since their voting patterns are similar over time.

Religion: Religious denomination of the respondent is measured using the following question in the DPES surveys: 'Do you consider yourself a member of a particular church or religious community, and if so, which one? In the 1971-7 and 2002 surveys the question asked was a two-step question. We distinguish those without a religious affiliation, Catholics, Protestants, Calvinists, and those having another denomination.

Economic conservatism: In all election surveys there is a question on income inequality that starts as follows: 'Some people think that the difference in incomes in our country should be increased (at number 1). Others think that these differences should be decreased (at number 7). Of course, there are also people whose opinion is somewhere in between.' Then there are four questions about where the respondent would place the four major political parties on this line. Finally respondents were asked: 'And where would you place yourself? We coded economic ideology such that the metric is running from 0 ('The differences in incomes in our country should be decreased') to 6 ('The differences in incomes in our country should be increased').

(p.216) Church attendance: In each survey respondents were asked how often they attended religious services: (1) at least once a week; (2) two or three times a month; (3) once a month; (4) several times a year; (5) never. We coded church attendance such that a high score refers to more attendance (0-4).

Party choice: We define four groups of political parties: old left, confessional, free-market right, and new left. We will focus on the contrast between old left and free-market right, the contrast between the confessional right and all other parties, and the contrast between new left and free-market right.

Party positions. To determine the ideological position of party groups we use data from the Comparative Manifesto Project (Budge et al. 2001; Klingemann et al. 2006). We construct three scales: (1) traditional morality; (2) economic left-right; (3) conservatism-progressivism.

With regard to the position of parties regarding traditional morality (i.e. cultural conservatism) we use the emphasis in the manifesto placed on positive statements about 'traditional morality'. This item was measured as the number of 'quasi-sentences' as a percentage of the total manifesto text dedicated to a 'favourable mention of traditional moral values; prohibition, censorship, and suppression of immorality and unseemly behaviour; maintenance and stability of family, and religion'. Because our dependent variable consists of party groups instead of individual parties we constructed a weighted mean of this scale by party group for each election year. The weight of a party within this group is determined by its vote share in percentages. Because the CMP data only includes 'significant' parties not all parties in Dutch post-war history are covered. Therefore, the positions of minor religious parties (RPF, GVP, $S G P)^{4}$ are not included in calculating the position of the religious party group on the traditional morality scale.

Second, we construct a left-right party position based on socio-economic issues. We use three policy categories from the CMP data files: 'planned economy' (i.e. market regulation and economic planning), 'welfare' (social justice and welfare state expansion), and 'market economy' (free enterprise and economic orthodoxy). Next, we add three policy categories on social groups: 'labour groups' (positive mentions of working class and trade unions), 'middle class and professional groups' (positive mentions) and 'labour groups: negative' (negative mentions of working class and unions). We create a social-economic left-right position by combining the categories as ((market economy + middle-class groups + negative labour groups)—(planned economy + welfare + labour groups). Hence, a higher score on this scale (-33.9-18.1) (p.217) corresponds to a more rightist party position. Again, the weight of a party within the group-mean is determined by its vote share in percentages. ${ }^{5}$

Third, in a similar vein we constructed the progressive policy positions of party groups associated with the left-libertarian ideology. We employ the scale construction procedure of Keman and Pennings 
(2006) who use the five policy categories to measure the emphasis on progressive issues, and five categories to measure conservative issues. The progressive issues are: 'anti-growth economy', 'national way of life: negative' (i.e. appeals to patriotism/nationalism), 'multiculturalism: positive', 'traditional morality: negative' (i.e. opposition to traditional moral values), and 'environmentalism: positive'. The conservative issues are: 'social harmony' (e.g. need for society to see itself as united), 'national way of life: positive', 'multiculturalism: negative', 'traditional morality: positive', and 'middle-class groups: positive'. We create a progressive position (progressive issues - conservative issues) which runs from -1.2 (conservative) to 18.0 (progressive).

In the multivariate analyses we control for education, age $(17=0)$, and gender (male $=0)$. We measure the educational level of the respondent as the number of years it normally takes to obtain a certain level of education. The educational categories in the original files are recoded using the conversion tables of Ganzeboom and Treiman (2009). In general this results in a metric running from four years for incomplete primary education $(=0)$ to eighteen years for complete university level $(=$ 14).

\section{Analysis}

To test the hypotheses we divided our analyses into two parts. First we examine the association between religion and vote, and then the class-vote association. Each part consists of four steps. First we examine the association between cleavages (class/religion) and ideologies (economic conservatism/religiosity). Second, we show how cleavage voting has changed over time. With respect to religious voting we employ logistic regression with a binary dependent variable contrasting religious parties (1) versus other parties (0). With respect to class voting we model over-time changes by employing multinomial logistic regression for voting old left versus liberal right and new left versus liberal right. The results of these models will be presented in figures as odds ratios. Third, we present the parameter estimates of multivariate logistic/multinomial regression models to formally test to what extent declining trends in cleavage voting are

Table 9.1. Mean church attendance (0-4) by religious group in 1971 and 2006

\section{$19712006 \quad 1971$ vs 2006}

$\begin{array}{lcccccc}\text { Religious group } & \mathbf{N}(\%) & \text { Mean s.d. } & \mathbf{N}(\%) & \text { Mean sd. Compare means } \\ \text { Non-members } & 743(29.8) & 0.00 & 0.00 & 1424(54.3) & 0.00 & 0.00 \mathrm{n} / \mathrm{a} \\ \text { Catholic } & 886(35.5) & 3.14 & 1.16 & 629(24.0) & 1.51 & 1.14-1.63^{* * *} \\ \text { Protestant } & 528(21.2) & 2.36 & 1.27 & 316(12.1) & 1.90 & 1.70-0.46^{* * *} \\ \text { Calvinist } & 226(9.1) & 3.51 & 1.03 & 100(3.8) & 2.55 & 1.88-0.96^{* * *} \\ \text { Other religion } & 112(4.5) & 2.55 & 1.27 & 153(5.8) & 2.22 & 1.83-0.33^{*} \\ \text { Total } & 2495(100) & 2.05 & 1.70 & 2622(100) & 0.82 & 1.41-0.64^{* * *} \\ \text { F-test (all religious groups) } & 1193^{* * *} & 557^{* * *} \\ \text { F-test (excl. non-members) } & 71.1^{* * *} & & 18^{* * *}\end{array}$

Source: DPES 1971 and 2006; ${ }^{*} p<.1^{* *} p<.05^{* * *} p<.01$

(a) T-test for equality of means

(p.218) accounted for by bottom-up changes and/or top-down changes. Finally, we show figures and use conditional logistic regression models to test whether changes in party positions account for changes in cleavage voting. 


\section{Denomination and Church Attendance}

First, we investigate part of the bottom-up explanation for the decline of religious voting which assumes that the association between denomination and church attendance has declined. In Table $\underline{9.1}$ we present the mean levels of church attendance broken down by denomination for 1971 and 2006 . The findings clearly suggest a blurring effect, that is, the association between church membership and religiosity (as indicated by church attendance) declines. This supports the blurring hypothesis $2 \mathrm{c}$. For all denominations church attendance is lower in 2006 compared to 1971. For Catholics the average church attendance becomes about half the size, dropping from 3.1 in 1971 to 1.5 in 2006. Also the mean attendance of Protestants, Calvinists, and those with another religion is significantly lower in 2006 than in 1971. The differences between religious groups decrease as well: as indicated by the Fstatistics (between-group variance/within group variance), differences between religious groups are lower in 2006 than in 1971.

\section{Religious Cleavages and Voting Confessional}

Next we show the over-time results of the denomination-vote relationship. We present the results of logistic regression models that regress religious voting (religious party vs. any other party) on being Catholic, Protestant, Calvinist, or having another religion $(\mathrm{N}=16.129)$. The reference group in (p.219) the analysis is those without a denomination. To allow for changes over time we add dummy indicators for each survey year with 1971 as the reference, as well as interactions between yeardummies and the religious groups. In Figure 9.2a we present, for each denomination for each year, the odds ratio of voting for a religious party versus any other party as opposed to the non-religious.

It is clear that the odds ratio of casting a religious vote is highest for Calvinists followed by Catholics, Protestants, and those with any other religion. In 1972 the odds that Calvinists voted for a religious party were 172 times the odds of the non-members. For Catholics and Protestants and those with another religion the 1972 odds ratios of voting were 30,15 and 11 times higher, respectively. However, there has been a strong decline of the denomination-vote relationship after the $1970 \mathrm{~s}$. The odds ratio for the Calvinists, although peaking again in 1998, eventually dropped to 30 times in 2006. The odds ratios of Catholics and Protestants casting a religious vote relative to the non-members dropped from 30 and 15, respectively, in 1972 to 8 in 1986. From 1986 onwards hardly any difference between Protestants and Catholics remains and together with the other religious people the odds of these groups are, compared to the non-members, about 4 to 10 times higher throughout the 19862006 period.

Figure $9.2 \mathrm{~b}$ shows that al most the whole trend can be interpreted by taking church attendance into account (note that we reduced the $y$-axis by a factor 5). We allowed the effect of church attendance to change linearly over time. The results indicate that the odds of Catholics voting for a religious party are about the same in 1971 and 2006 (about 2 times higher compared to the non-members). The odds of Protestants are in fact about 2 times higher in 2006 than in 1971. In 1972 the odds of Calvinists casting religious vote are about 16 times higher than for the non-members. In 1986 this odds ratio drops to about 3, but rises again to 25 in 1998 and then 12 in 2006. We conclude that the decline of church attendance and therefore the decline in religiosity among church members is almost fully responsible for the decline in and for the convergence of religious-based voting, which strongly supports hypothesis 2 . However, decreasing religiosity is not able to interpret the alleged increase in religious voting between 1986 and 1998..$^{6}$

To get more insight into these changes and to test our hypotheses formally we present logistic regression models. In our first model in Table $\underline{9.2}$, we tested for changes over time in the association between denomination and vote. To ensure our model is parsimonious we allow each denomination parameter to vary linearly over time. With 1971 as a baseline, all religious groups are (p.220) 


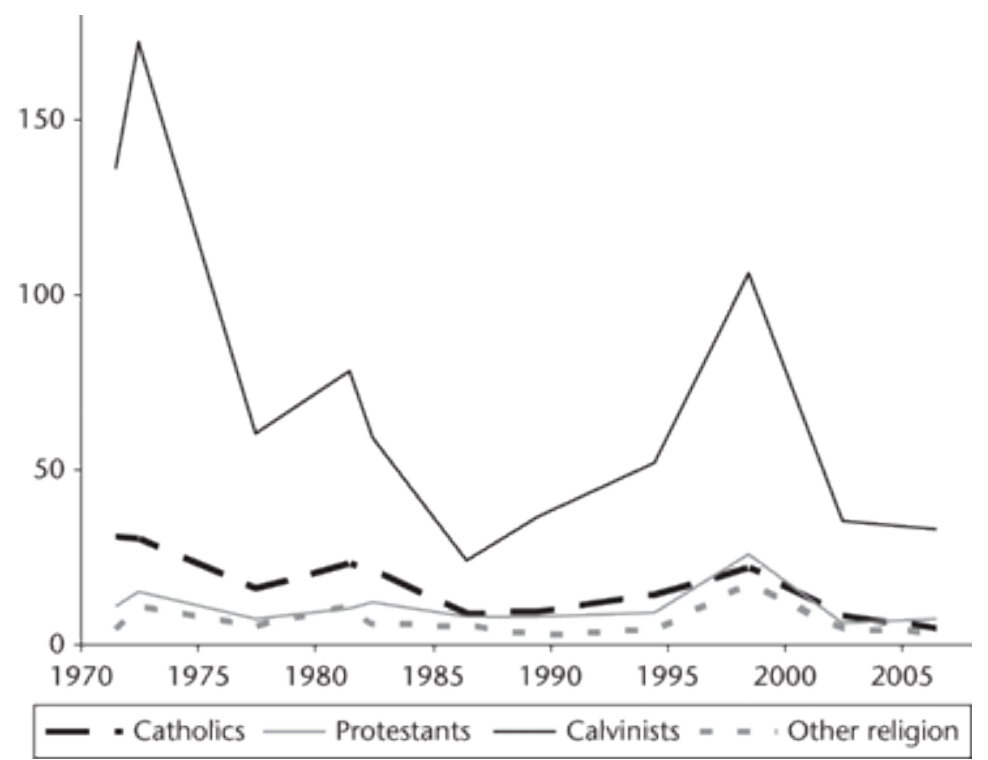

Figure 9.2a. Odds ratios for voting religious (non-members as reference group).

Source: DPES 1971-2006.

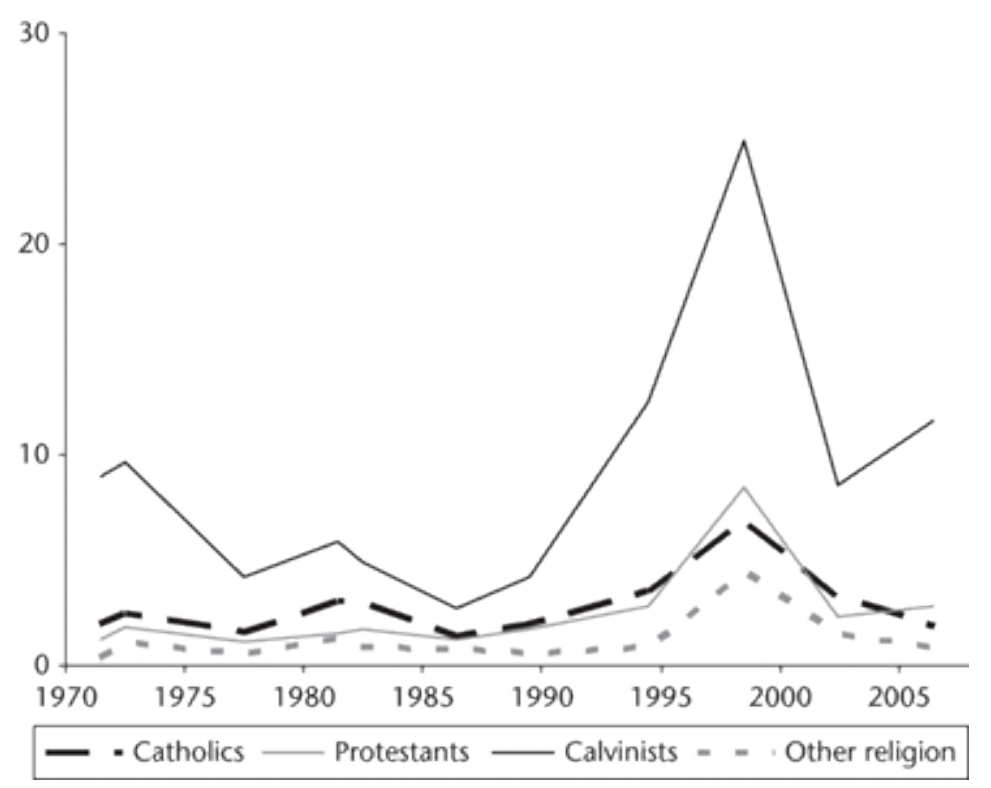

Figure 9.2b. Odds ratios for voting religious (non-members as reference group) controlled for church attendance.

Source: DPES 1971-2006.

(p.221) significantly and substantially more likely to cast a confessional vote than those without a denomination. The odds of voting for a confessional party in 1971 in contrast to the non-members are $\left(\mathrm{e}^{3.282}\right) 26$ times higher for Catholics, 9 times higher for Protestants, 97 times higher for Calvinists, and 5 times higher for other religious groups. However, there are clearly blurring effects for all denominations, with the strongest linear decline for the Catholics and the Calvinists. Between 1971 and 2006 the odds of Catholics voting for religious parties relative to non-members fell from 26 to about $5\left(\mathrm{e}^{3.282-\left(35^{*} \cdot 048\right)}\right)$. There is an even stronger decline for Calvinists. In 1971 the odds of Calvinists voting for a confessional party were 97 times higher than for unaffiliated voters, but this drops to 27 times in 2006. These results clearly support hypothesis $1 \mathrm{a}$. 
In model 2 we add the bottom-up changes to the model. We expected that social changes would be able to account for the decline of the association between denomination and vote. As well as church attendance we also include variables for education and allow these effects to vary linearly over time. The negative main effect of education indicates that the odds that one votes for a religious party in 1971 are about 7 per cent lower for each year of education. The positive year* education interaction suggests that the effect of education becomes weaker over time. The positive main effect of church attendance shows that in 1971 the odds of voting for a religious party are higher the more frequently one attends church. The negative year ${ }^{*}$ church attendance interaction implies that the effect of church attendance is declining over time. Although both the effects of education and church attendance are significant, it is largely church attendance that accounts for the decline in religious voting. When we estimate model 2 without church attendance the effects of the year ${ }^{*}$ denomination interactions are the same as in model 1.

Model 2 demonstrates two things. First, the effect of church attendance gradually declines $(-0.010)$. Second, the decline of the church attendance-vote association largely interprets the decline of the denomination-vote association, which supports hypothesis 2a. Accounting for the decline in the effect of church attendance model 2 shows that the odds of all religious groups casting a vote for a religious party relative to unaffiliated voters have fallen. With 1971 as a baseline, the odds for Catholics fall to 2, for Protestants to nearly 1, and for Calvinists to 5.5. Voters with another religion are even less likely to vote for a confessional party. Moreover, the decline of the effects of being Catholic and being Calvinist, relative to non-members, are also no longer significant. Interestingly, for Protestants, their denomination now becomes increasingly important, that is, up to an odds ratio of 3 in 2006. This suggests that the extent to which church members attend religious services is of decreasing importance for confessional voting, which largely interprets the decline in religious voting for Catholics, Protestants, and Calvinists. Being a Protestant becomes more important for casting a religious vote between 1971 and 2006.

(p.222)

Table 9.2. Logistic regression for voting for religious parties versus all other parties in the Netherlands, 1971-2006

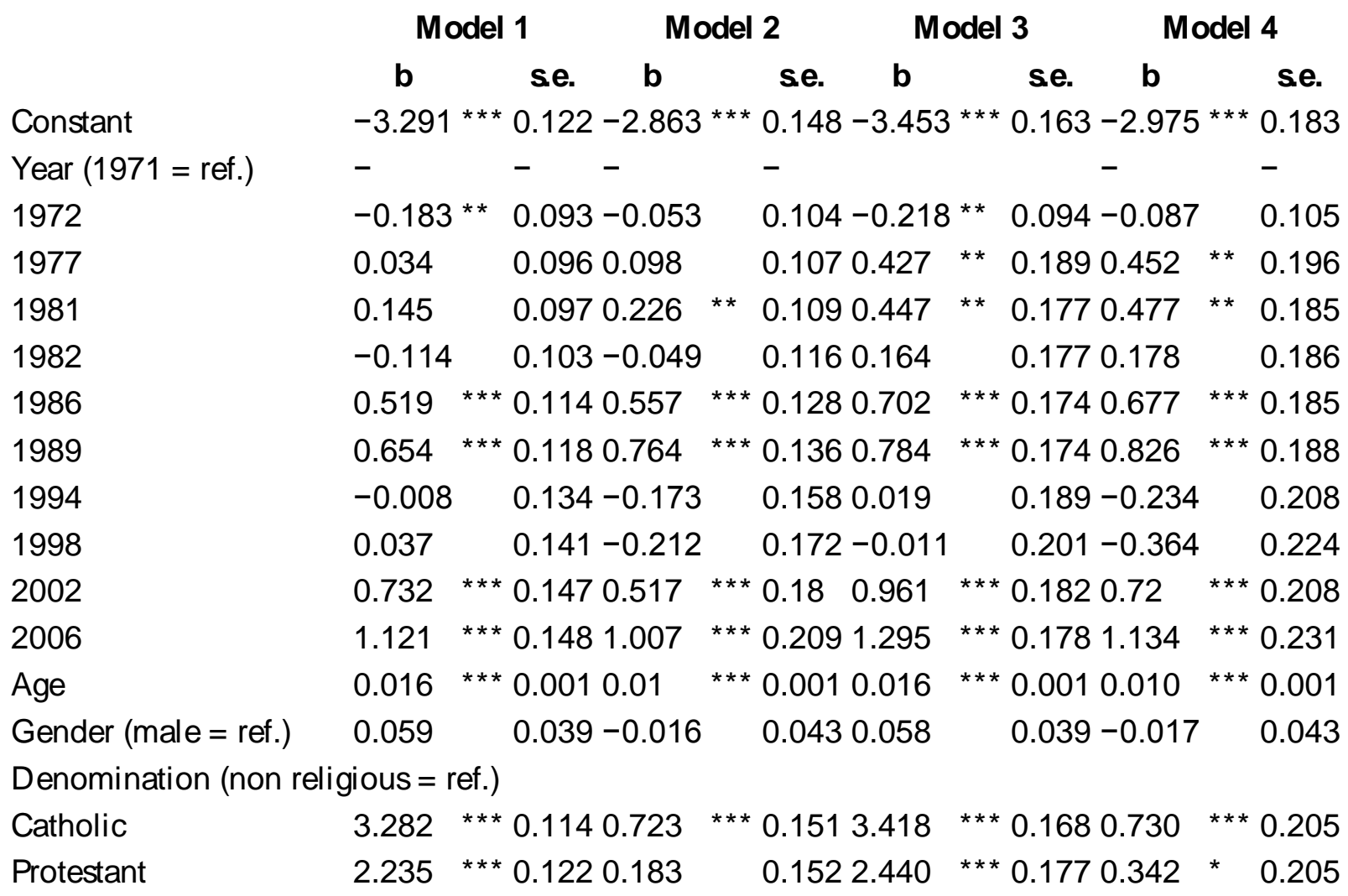


Calvinist

Other religion

Trend

Year ${ }^{\star}$ Catholic

Year* Protestant

Year*Calvinist

Year ${ }^{\star}$ Other religion

Bottom-up

Education in years

Year* education in years

Church attendance

Year* ${ }^{*}$ church attendance

Top-down

CDA merger since 1977

$1977^{*}$ Catholic

$1977^{*}$ Protestant

$1977^{\star}$ Cal vinist

CU merger since 2002

$2002^{*}$ Catholic

2002* Protestant

$2002{ }^{*}$ Calvinist

Df

$-2 \mathrm{LL}$
Model 1

b

se. b

Model 2

Model 3

Model 4

$4.579^{* * *} 0.1581 .716^{* * *} 0.1955 .024^{* * *} 0.2302 .1944^{* * *} 0.266$

$1.704^{* * *} 0.199-0.595^{* *} 0.2371 .7433^{* * *} 0.202-0.61 * * 0.240$

\begin{tabular}{|c|c|c|c|c|c|}
\hline * & 6 & & 7 & 0 & \\
\hline & & $* 0.007$ & .023 & 0.0120 & \\
\hline & & & 0.003 & 0.0 & 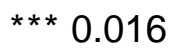 \\
\hline & .00 & 0.01 & -0.015 ** & 0.0090 .022 & \\
\hline
\end{tabular}

$-0.066^{* * *} 0.012$

$-0.067^{* * *} 0.012$

$0.001^{* * *} 0.001$

$0.002^{* * *} 0.001$

$0.840^{* * *} 0.034$

$0.851^{* * *} 0.034$

$-0.010 * * * 0.002$

\section{${ }^{*} p<.1^{* *} p<.05^{* * *} p<.01 ; N=16,129$}

$$
\begin{array}{lll}
-0.464^{* *} & 0.232-0.350 & 0.242 \\
-0.732^{* * *} & 0.254-0.800 * * & 0.268 \\
-1.108^{* * *} & 0.331-1.418^{* * *} 0.351 \\
-0.432^{* *} & 0.211-0.542 * * & 0.218 \\
-0.674^{* * *} & 0.244-0.801 * * & 0.258 \\
-0.320 & 0.319-0.619 * * & 0.335
\end{array}
$$

24

14159.4
26

15680.8
30

14131.6

(p.223) (p.224) In model 3 we test two of the political change hypotheses. To test whether the association between denomination and vote for religious versus non-religious parties shows an abrupt decline after the 1977 election when the CDA came into existence, we include an interaction between denomination and a dummy that indicates the 1977 merger of the three main religious parties. This way we test whether there was an abrupt decline in confessional voting which coincides with the formation of the CDA (cf. De Graaf et al. 2001). We also include an interaction between denomination and a dummy indicating the 2002 election when the two minor Protestant parties merged into the ChristianUnion. In support of hypothesis 5 the estimates indeed show that the 1977 CDA merger seems to be responsible for a decline in confessional voting for the Catholics $\left(\mathrm{e}^{-0.464}\right)$, Protestants $\left(\mathrm{e}^{-0.732}\right)$ and Calvinists $\left(\mathrm{e}^{-1.108}\right)$. That is, after the CDA merger the odds of Catholics voting for a religious party fell to 60 per cent of their pre-1977 level, whereas the odds for Protestants fell to about a half, and the odds for Calvinists to a third of their original level. The 2002 interactions suggest that there was also an abrupt decline in religious voting for Catholics and Protestants after the 2002 election. Also after 2002, the odds of voting for a religious party fell to about 60 per cent of their level before 2002 for Catholics, and to about a half for Protestants. The ChristianUnion merger did not affect the odds of voting confessional for Calvinists. Of course, the 2002 elections were heavily influenced by the parliamentary entrance of the List Pim Fortuyn (LPF). Although the rise of the LPF caused massive shifts among the electorate, it is unlikely to be responsible for the abrupt decline of the linear trend in religious voting in 2002. There is no obvious relationship between specific denominations and voting LPF. ${ }^{?}$ 
In model 4 we include the bottom-up changes (i.e. education, church attendance) and top-down changes (i.e. party mergers) simultaneously. The results indicate that the gradual decline in the association between denomination and vote is accounted for, but abrupt decreases associated with political changes remain. Actually, we find that the odds of voting confessionally for all major denominations gradually increase in the period 1971-2006, but show sudden decreases after 1977 (for Protestants and Calvinists) and 2002 (for all denominations). This model supports the idea that after accounting for social changes and party mergers, there may be other factors that increase religious voting despite the weakening of religious integration and the 'depillarization' of the party system. In other words, accounting for church attendance (p.225) interprets much of the decline in religious voting, and party mergers may explain sudden decreases in religious voting, but these factors leave unexplained why the odds of voting for a religious party for all denominational groups now increase over time, particularly after 1986 (see Figure $\underline{\text { 9.2b) }) . ~}$

Next, we look at changes in the emphasis on traditional values in the party manifestos between 1971 and 2002. Unfortunately these data are not yet available for the 2006 election. In Figure $9.3 a$ we not only present the positions regarding traditional morality for religious parties, but we also show the positions of the old left parties, new left parties and free-market liberal parties. Figure 9.3a shows that since the 1970s religious parties have been mentioning issues around traditional morality less and less in their manifestos, but only up until 1982. After 1982 traditional values become more salient again in the party programmes of religious parties. The common perception that the Christian Democrats in the Netherlands adjusted their party programme to match the changing religious structure of society by deemphasizing traditionalist issues is therefore not supported by the pattern in Figure 9.3a. The traditionalist position of the religious party group in 2002 is at about the same level as in 1972. It is therefore unlikely that accounting for the positions of religious parties will explain the linear decline in religious-based voting. Figure 9.3 a shows that there is hardly any variation among the other political parties over time.

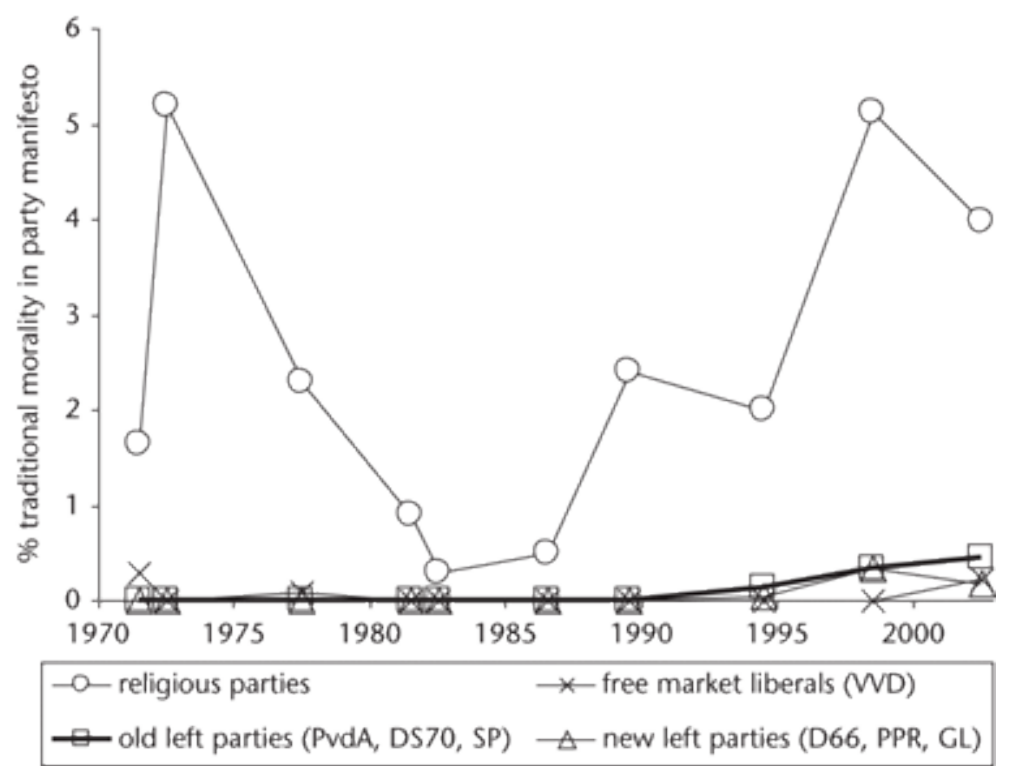

Figure 9.3a. Emphasis of traditional morality issues in party manifestos by political party group.

Source: Comparative Manifesto Project (2001, 2006). 


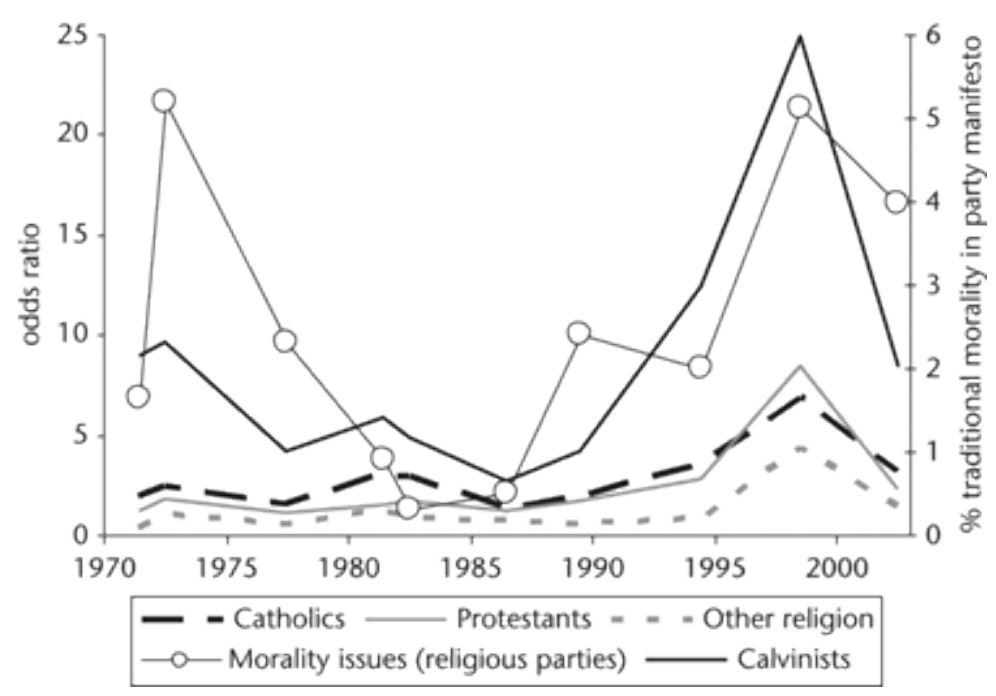

Figure 9.3b. Controlled odds ratios for voting religious (non-members as reference group) and the emphasis of traditional morality issues in party manifestos of religious parties.

Source: Comparative Manifesto Project $(2001,2006)$ and DPES 1971-2006.

In Figure 9.3b we overlay the manifesto-pattern for religious parties with the patterns in religious-based voting as reported in Figure 8.3b (controlled for the declining effect of church attendance). We observe that for Calvinists the odds ratios of voting for a religious party relative to unaffiliated voters follow a very similar pattern to the emphasis on traditional values in the manifestos of religious parties. We can therefore conclude that political choice indeed matters. Also the increase of religious voting for Catholics, Protestants, and those with another religion from 1986 onwards seems to coincide with an increase of the salience of traditionalist issues in religious party programmes. The more religious parties emphasize issues related to traditional moral values the less non-members and the more religious voters are inclined to vote for these parties.

To formally test this top-down hypothesis we applied conditional logistic regression (McFadden 1974). Conditional logistic regression enables us to model individual voting behaviour by taking into account the positions of parties (日ff 2009). In our analyses these positions are the values of the religious parties as well as three other party groups (old left, new left, liberal right) with respect to their position on traditional moral values. Because there are no manifesto data available for the 2006 elections, we excluded this year. For reasons of parsimony and to avoid too many technical details we will provide only the main conclusions of this analysis. The results show that traditionalist (p.227) party positions increase religious voting despite the weakening of religious integration and the restructuring of the party system. We find an interaction between religious categories and the ideological positions of parties. Non-affiliated voters in particular are less likely to vote for parties that hold traditional moral positions. In this sense we may conclude that parties with more traditional moral positions deter secular voters rather than attract religious voters. We aimed to investigate whether the traditionalist positions of parties could interpret the decline in religious-based voting after accounting for social changes that reduce religious boundaries. However, since the decline of church attendance is almost fully responsible for the decline in religious-based voting (hypothesis $3 a$ is therefore not relevant anymore), party positions do not contribute to explaining linear downward trends. After accounting for a declining effect of church attendance a $U$-curve for religious voting remained. Modelled as a linear increase in religious-based voting this trend is to some extent explained by the traditional moral positions of parties. Finally, the effect of church attendance did not decline after inclusion of the ideological positions of parties (hypothesis 4a). 


\section{Social Class and Economic Conservatism}

Next we investigate changes in class voting. We start by testing the blurring hypothesis $2 \mathrm{~d}$, namely that the association between class and economic ideology declines. For this purpose we regressed economic conservatism on social class and dummy indicators for surveys. We assumed linear trends for the change of the class effects. In Figure 9.4 we report the regression coefficients for the reference year 1971 and the calculated class effect for 2006 based on the linear trend. We observe a decrease in the association between class position and economic conservatism for all classes when compared to the manual class. However, this linear decrease is only significant at the 5 per cent level for the higher technocrats and the lower social-cultural specialists. Hence, we have weak support for the blurring hypothesis 2d. In 2006 the associations between ideology and the (higher and lower) social-cultural specialists or the routine non-manual class are not much different from the association between ideology and the manual class. As expected, both the higher and lower technocrats and self-employed are the most economic conservative classes in 2006, which illustrates the political difference of the technocrats and social-cultural specialists. In earlier work, Van Wijnen (2000) concluded that for the 1971-98 surveys there is no systematic difference over time in the association between subjective class orientation and left-right ideology. Our results are different, and this difference in conclusions may be explained by our use of a detailed objective class measure, our use of more recent elections, and/or a different measure of ideology. (p.228)

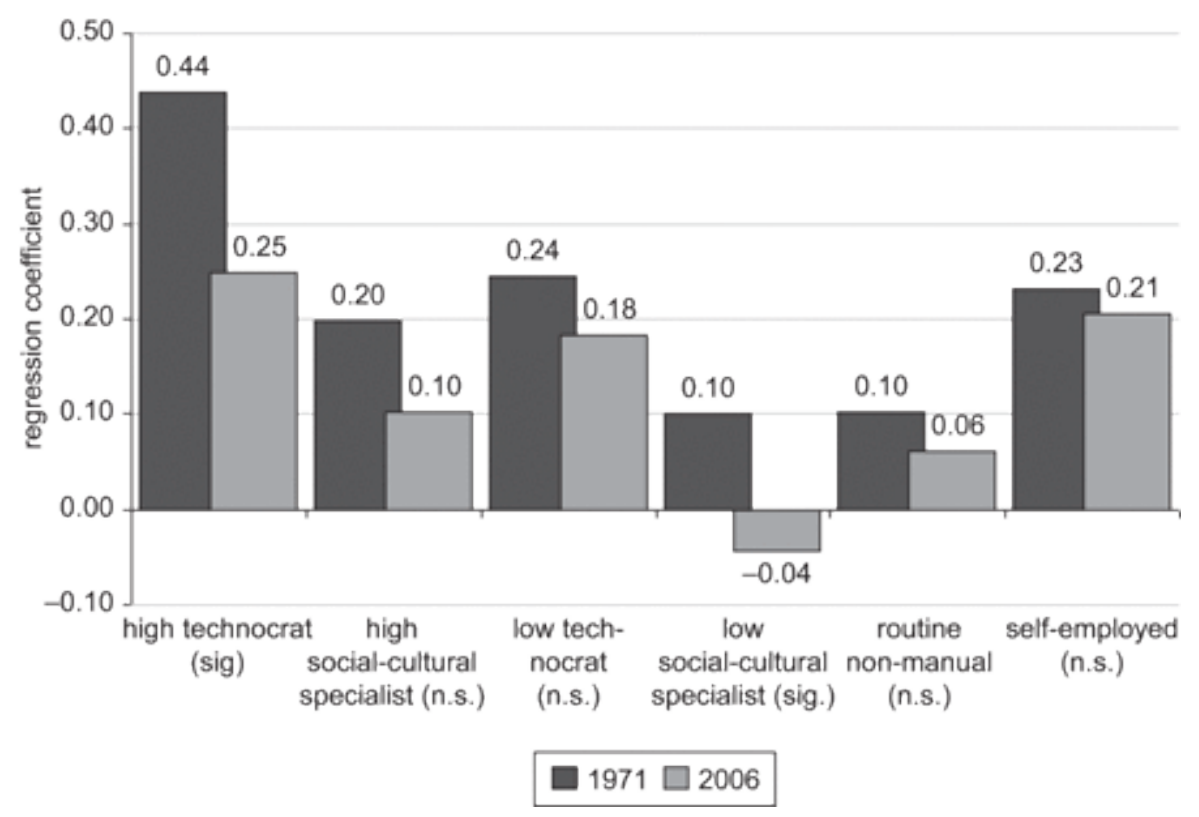

Figure 9.4. Economic conservatism regressed on social class (manual class is reference group) and year of survey assuming linear trends for the effect of social class (DPES 1971-2006).

sig = linear trend effect significant at the 5 per cent level. Economic conservatism is measured using three-point scale in order to make 2006 as comparable as possible with 1971.

\section{Class Cleavages and Voting Old Left and New Left versus Free-market Right}

To analyse the changing class-vote association we employ multinomial logistic regression models. We concentrate on the contrasts between old left versus liberal right and new left versus liberal right; respondents with another party choice are excluded from the analyses $(\mathrm{N}=8,023)$. Again we start by adding dummy indicators for each year of survey with 1971 as the reference, as well as interactions between year-dummies and the class-groups. In Figures $\underline{9.5 \mathrm{a}}$ and $\underline{9.5 \mathrm{~b}}$ we first look at the odds ratios of voting for old left versus liberal right parties over time. The reference group in the analysis are people in the manual class. An odds ratio above 1 (ranging to infinite) indicates that the odds of voting old left versus liberal right are higher than in the manual class. Negative associations are indicated by odds ratios ranging between $0-1$. In order to make the scale in Figures $9.5 \mathrm{a}$ and $9.5 \mathrm{~b}$ comparable for 
positive and negative association we present negative associations as -(1/odds ratio). We start with a comparison of the lower and upper service class, routine non-manual class, and the self-employed relative to the working class. Figure 9.5 a shows that the high service class is least likely to vote old left followed by the self-employed and low service (p.229) class/routine non-manual class, and that until 2002 the differences with the manual class decline. This indicates a process of class dealignment.

To illustrate how important changes in the occupational structure are for understanding these changes in the class-vote relationship we report in Figure $9.5 \mathrm{~b}$ the odds ratios for the higher technocrats, the lower technocrats, and the lower social-cultural specialists. Due to the lack of a sufficient number of cases for each year we do not report the higher social-cultural specialists. Figure $9.5 \mathrm{~b}$ shows that until 1981 there was not much difference between the low technocrats and the lower social-cultural specialists relative to the manual class. After that it goes up and down and stabilizes from 1998 onwards. After 1994 the lower social-cultural specialists are even more likely to vote left-wing than the manual class, suggesting a process of class realignment, although the differences from the manual class are very small. This shows that it becomes increasingly important to decompose the service class in order to understand the evolution of class voting. We see that the higher technocrats are far less likely to vote old left relative to the manual class than the other classes in the service class. The differences between the lower and higher technocrats seem to have weakened since the 1970s, and from 1989 onwards there is hardly any difference.

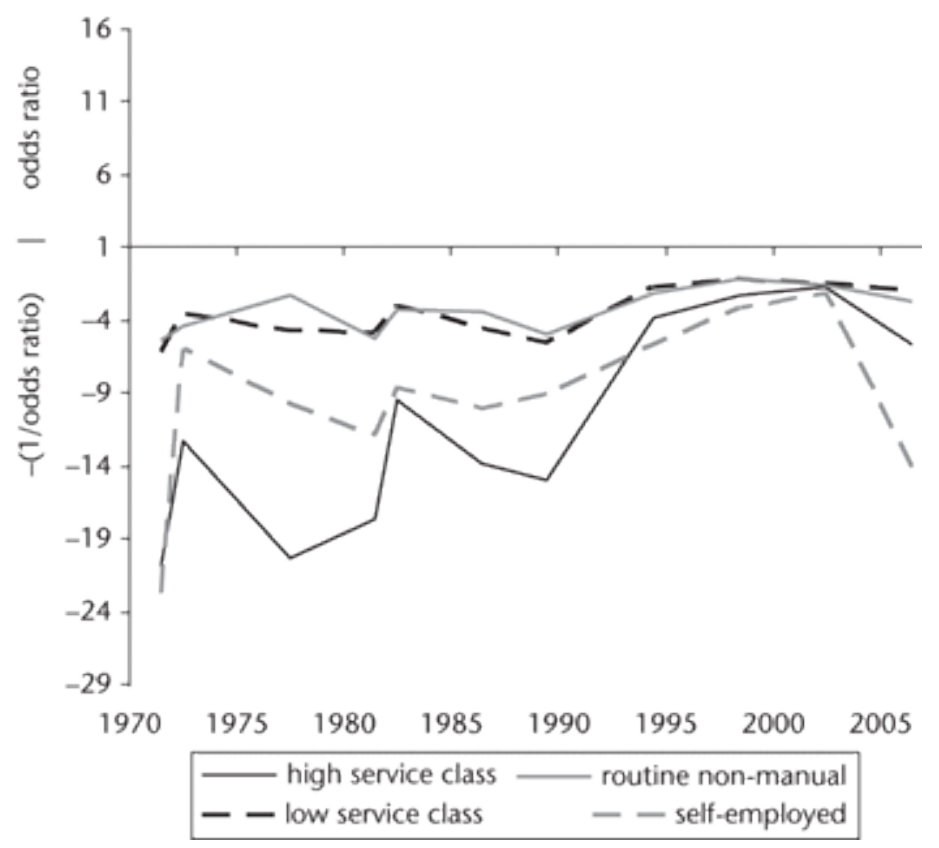

Figure 9.5a. Odds ratios for voting old left versus liberal right (manual class as reference group). 


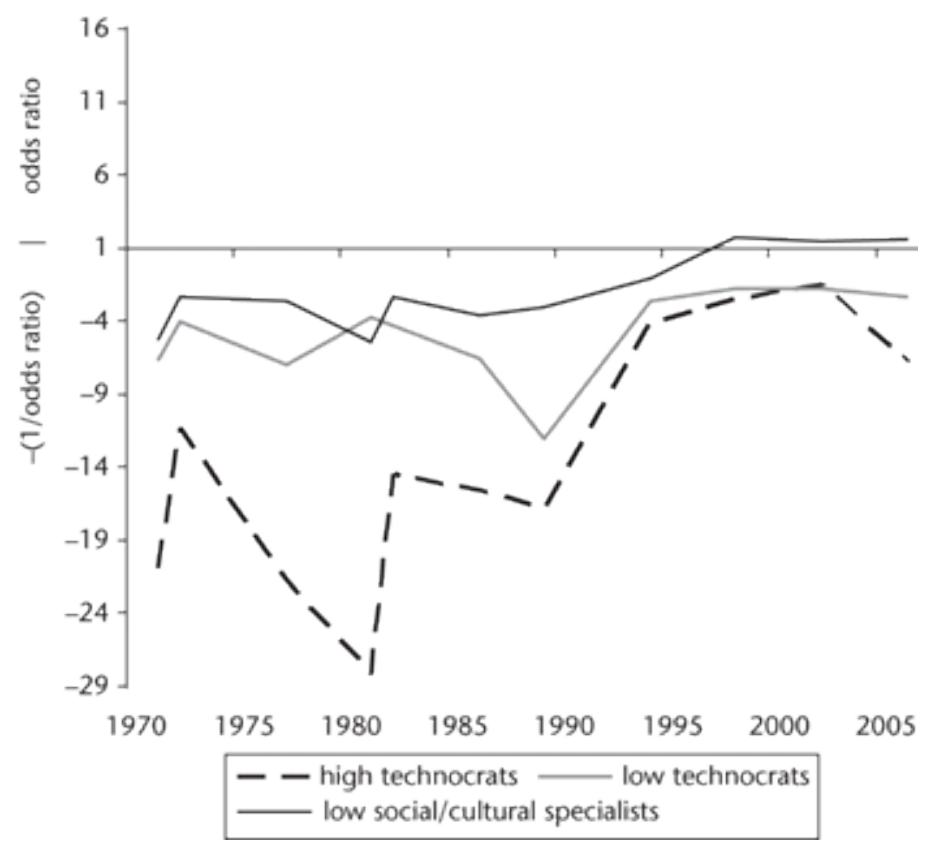

Figure 9.5b. Odds ratios for voting old left versus liberal right (manual class as reference group).

Next, in Figures $\underline{9.6 \mathrm{a}}$ and $\underline{9.6 \mathrm{~b}}$ we investigate the odds ratios of voting new left versus liberal right. Figure 9.6 a shows that in general the self-employed are least likely to vote new left versus liberal right, following by the high service class, routine non-manual class, and low service class. We clearly observe a process of convergence: all classes, especially the high service class are increasingly likely to cast a new left vote relative to voting liberal right. From the mid 1990s there is hardly any difference between the working class and the low service class/routine non-manual class. In 2006 manual class voters were very unlikely to vote for a new left party, and even the odds for the high service class to vote new left versus liberal right were higher than for the manual class.

With respect to the sub-classes within the service class Figure $9.6 \mathrm{~b}$ shows a process of class dealignment, that is, the new left/liberal right voting behaviour of the (higher and lower) technocrats is converging towards the manual class. For the low-grade social-cultural specialists we observe a process of realignment. This class initially voted similarly to the manual class, but became increasingly more likely to vote for a new left party relative to casting a liberal right vote.

In Tables $\underline{9.3 \mathrm{a}}$ and $\underline{9.3 \mathrm{~b}}$ we present the multinomial parameter estimates of voting old left and new left versus liberal right. In our first model we allow the class effect to change linearly over time and we control for age and gender. In (p.231) 


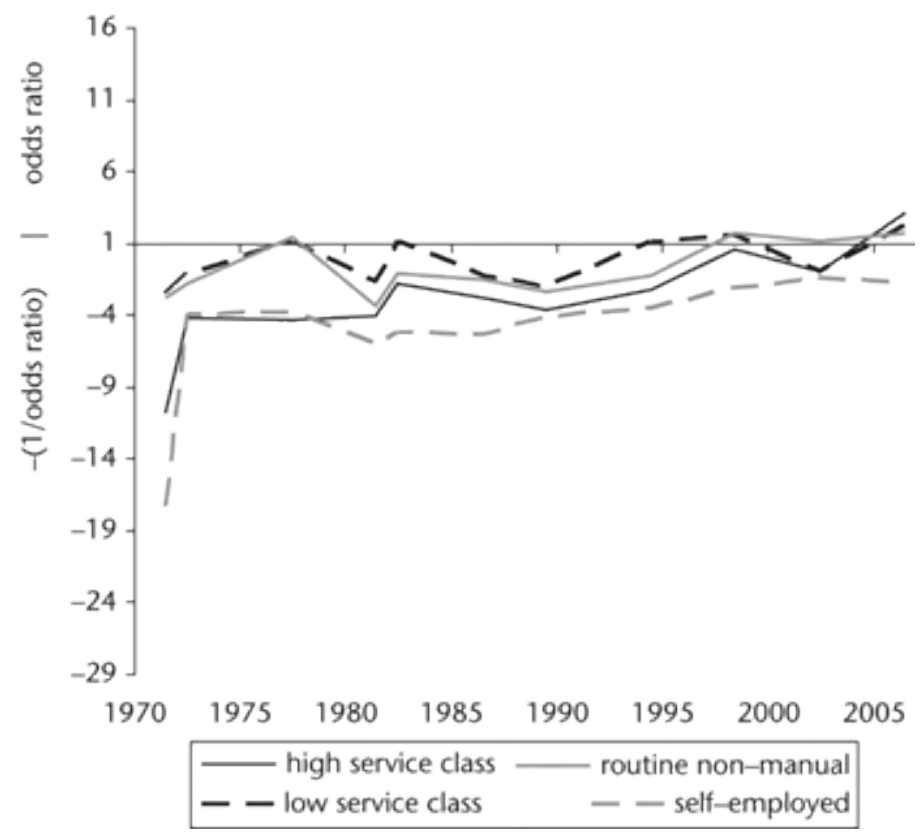

Figure 9.6a. Odds ratios for voting new left versus liberal right (manual class as reference group).

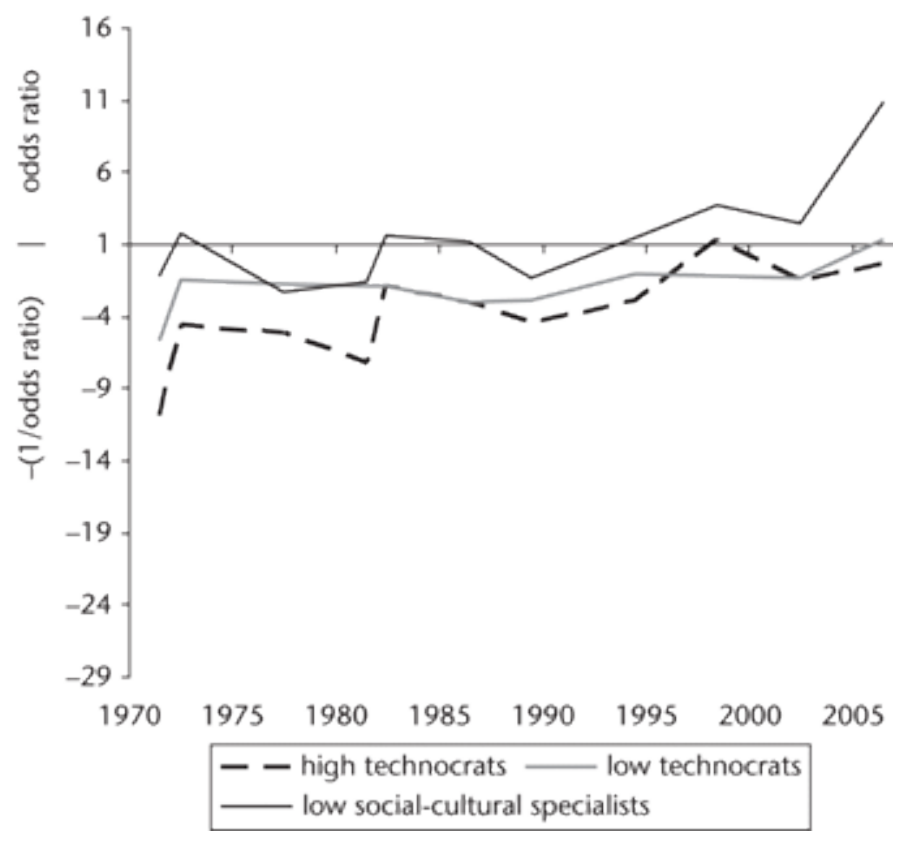

Figure 9.6b. Odds ratios for voting new left versus liberal right (manual class as reference group).

(p.232) later models we include years of education in order to investigate to what extent changes in class voting are due to educational differences.

With respect to voting old left versus liberal right, model 1 in Table 9.3a shows gradual decreases in class differences for almost all classes relative to the manual class. The negative main-effects of the class-year interactions indicate that in 1971 the odds of voting old left rather that liberal right are lower for other classes than for the manual class. The significant positive year-interactions for the higher and lower technocrats, lower social-cultural specialists, routine non manual class, and self-employed imply that the distinction between these classes and the manual class for voting old left versus a free-market liberal party become less important each year. The effects indicate that in 1971 the odds for higher technocrats to vote old left were about $\left(1 / \mathrm{e}^{-3.165}\right) 23$ times lower than the odds for the manual class, compared to about 3 times lower in 2006. For low-grade technocrats the odds are about 7 and 2 times lower, respectively, compared to the manual class in 1971 and 2006. Most remarkable is that, based 
on a linear trend, the odds for low-grade social-cultural specialists are 5 times lower than the odds for the manual classes in 1971, and they are 1.5 times higher in 2006.

We also observe gradual changes in class differences with respect to voting new left versus liberal right. The differences between manual workers and the class of social-cultural specialists were relatively small in 1971. In the reference year, we find no significant difference in the odds of voting new left between the high social-cultural specialists and manual class voters. We find that the odds for low-grade social-cultural specialists were only about 1.3 times lower than the odds for manual class voters. Over time, social-cultural specialists become more likely to vote new left rather than liberal right. Based on a linear trend we find that the odds of voting new left for both high and low socialcultural specialists increase to about 2.5 times the odds for manual workers in 2006 . Class differences between social-cultural specialists and manual workers have increased in the period 1971-2006. With respect to other classes we find that the differences relative to the manual class decline over the same period. Based on a linear trend, the tendency to vote new left versus liberal right for high and lowgrade technocrats and the routine non-manual workers virtually disappeared in 2006.

In model 2 we control for years of education, and allow the effect of education to change over time. With respect to voting old left versus liberal right we find that in 1971 more years of education suggested a rightist party choice $(-0.154)$. But as a result of a linear change in the education-vote association (0.04) this negative effect had nearly disappeared by 2006 . With respect to voting new left versus liberal right we find that since $1981(-0.020+10 * 0.002)$ more education is increasingly associated with casting a vote for a new left party. Education has the largest impact on class-effects with respect to voting old left versus liberal right. Especially for the sub-classes within the service (p.233)

Table 9.3a. Multinomial logistic regression for voting old left versus liberal right and new left versus liberal right parties in the Netherlands, 1971-2006

\section{Model 1}

\section{Old left vs New left vs} right

Constant

Year $(1971=$ ref. $)$

1972

1977

1981

1982

1986

1989

1994

1998

2002

2006

Age

Gender (male $=$ ref.)

High technocrats

High social-cultural

specialists

$$
\begin{aligned}
& -3.165^{* * *}(0.210)-2.171^{* * *}(0.253)-2.544^{* * *} \\
& (0.479)-0.820^{* *}
\end{aligned}
$$

b

se.

b

$2.319^{* * *}$

(0.169) $1.539^{\star * *}$

se.

(0.193) $3.137^{* * *}$

se.

(0.201) $1.625^{* * *}$

$-0.518^{* * *}$

$(0.173)-0.619^{* * *}$

$(0.197)-0.558^{* * *}$

(0.174) $-0.633^{* * *}$

$-0.369^{* * *}(0.164)-0.954^{* * *}(0.196)-0.517^{* * *}$

$(0.168)-1.010^{* * *}$

$-0.924^{* * *}(0.167)-0.450^{* *}$

$(0.185)-1.085^{* * *}$

$(0.174)-0.541^{* * *}$

$-1.238^{* * *}(0.164)-1.576^{* * *}(0.194)-1.390^{* * *}$

$(0.172)-1.680^{* * *}$

$-0.812^{* * *}(0.176)-1.181^{* * *}(0.209)-1.032^{* * *}$

$(0.190)-1.332^{* * *}$

$-0.738^{* * *}(0.184)-0.607^{* * *}(0.210)-1.033^{* * *}$

$(0.202)-0.785^{* * *}$

$-1.578^{* * *}(0.193)-0.758^{* * *}(0.219)-1.956^{* * *}$

(0.223) $-1.006^{* * *}$

$-1.510^{* * *}(0.210)-1.155^{* * *}(0.244)-2.013^{* * *}$

$(0.252)-1.453^{* * *}$

$-1.393^{* * *}(0.237)-0.800^{* * *}(0.275)-1.993^{* * *}$

$(0.279)-1.118^{* * *}$

$-0.994^{* * *}$

$(0.251)-2.047^{* * *}$

$(0.309)-1.704^{* * *}$

$0.005^{* * *}$

$(0.002)-0.022^{* * *}(0.003) 0.001$

$0.159^{* * *}$

(0.060) $0.199^{\star * *}$

(0.069) 0.081

(0.338) $-2.549^{* * *}$

$(0.002)-0.022^{* * *}$

(0.061) $0.194^{* * *}$

se.

(0.231) 


\section{Model 1}

Model 2

Old left vs New left vs Old left vsliberal New left vsliberal right

\begin{tabular}{|c|c|c|c|c|c|c|}
\hline & & & & & & \\
\hline & b & se. & se. & se. & b & se. \\
\hline Low technocrats & $-1.965^{* * *}$ & $(0.185)-1.105^{* * *}$ & $(0.221)-1.594^{* * *}$ & $(0.192)$ & $-1.043^{* * *}$ & $(0.229)$ \\
\hline $\begin{array}{l}\text { Low social-cultural } \\
\text { specialists }\end{array}$ & $-1.700^{* * *}$ & $(0.209)-0.304^{* * *}$ & $(0.230)-0.989^{* * *}$ & $(0.228)$ & -0.194 & $(0.252)$ \\
\hline Routine non-manual & $-1.568^{* * *}$ & $(0.158)-0.979 * * *$ & $(0.191)-1.325^{* * *}$ & $(0.161)$ & $-0.933^{* * *}$ & $(0.193)$ \\
\hline Self-employed & $-2.507^{* * *}$ & $(0.202)-1.922^{* * *}$ & $(0.273)-2.439^{\star * *}$ & $(0.204)$ & $-1.900^{* * *}$ & $(0.273)$ \\
\hline Trend & & & & & & \\
\hline Year*high technocrats & $0.057^{* * *}$ & $(0.010) 0.069^{* * *}$ & $(0.012) 0.039^{* * *}$ & $(0.010)$ & $0.062^{* * *}$ & $(0.013)$ \\
\hline $\begin{array}{l}\text { Year*high s-c } \\
\text { specialists }\end{array}$ & 0.028 & $(0.017) 0.050^{* \star *}$ & $(0.019)-0.006$ & $(0.018)$ & $0.041^{* *}$ & $(0.020)$ \\
\hline Year*low technocrats & $0.037^{* \star *}$ & $(0.009) 0.026^{* *}$ & $(0.011) 0.027^{* \star *}$ & $(0.009)$ & $0.021^{*}$ & $(0.011)$ \\
\hline $\begin{array}{l}\text { Year*low s-c } \\
\text { specialists }\end{array}$ & $0.059^{* * *}$ & $(0.011) 0.037^{* * *}$ & (0.013) $0.040^{* * *}$ & $(0.012)$ & $0.029^{* *}$ & $(0.013)$ \\
\hline $\begin{array}{l}\text { Year" routine non- } \\
\text { manual }\end{array}$ & $0.028^{* * *}$ & $(0.008) 0.030^{* * *}$ & $(0.010) 0.023^{* * *}$ & $(0.008)$ & $0.027^{* * *}$ & $(0.010)$ \\
\hline Yearself-employed & $0.024^{\star *}$ & $(0.011) 0.033^{* *}$ & $(0.014) 0.023^{* *}$ & $(0.011)$ & $0.032^{* *}$ & $(0.014)$ \\
\hline Bottom-up & & & & & & \\
\hline Education in years & & & $-0.154^{* * *}$ & $(0.020)$ & -0.020 & $(0.023)$ \\
\hline $\begin{array}{l}\text { Year*education in } \\
\text { years }\end{array}$ & & & $0.004^{* * *}$ & $(0.001)$ & $0.002^{*}$ & $(0.001)$ \\
\hline $\begin{array}{l}\text { Economic } \\
\text { conservatism }\end{array}$ & & & & & & \\
\hline $\begin{array}{l}\text { Year }{ }^{*} \text { economic } \\
\text { conservatism }\end{array}$ & & & & & & \\
\hline Df & 48 & & 52 & & & \\
\hline Deviance & 14212.4 & & 14102.6 & & & \\
\hline
\end{tabular}

Table 9.3b. Multinomial logistic regression for voting old left versus liberal right and new left versus liberal right parties in the Netherlands, 1971-2006

\section{Model 3}

\section{Model 4}

\section{Old left vsliberal New left vsliberal Old left vsliberal New left vsliberal right right right right}

b se. b se $b$ se. b

$\begin{array}{lllllll}\text { Constant } & 3.699^{* * *} & (0.223) 2.155^{* * *} & (0.249) & 3.730^{* * *} & (0.230) 2.195^{* * *} & (0.257) \\ \text { Year }(1971=\text { ref.) } & & & & & & \\ 1972 & -0.561^{* * *} & (0.183)-0.644^{* * *} & (0.204)-0.565^{* * *} & (0.183)-0.650^{* * *} & (0.205) \\ 1977 & 0.401^{* *} & (0.183)-0.178^{* * *} & (0.212) & 0.370^{*} & (0.193)-0.214 & (0.223) \\ 1981 & -0.100 & (0.190) 0.375^{*} & (0.206)-0.156 & (0.212) 0.308 & (0.234) \\ 1982 & -0.171 & (0.190)-0.574^{* * *} & (0.216)-0.230 & (0.216)-0.652^{* * *} & (0.250) \\ 1986 & 0.065 & (0.212)-0.319 & (0.241)-0.016 & (0.259)-0.439 & (0.300)\end{array}$




\section{Model 3}

\section{Model 4}

Old left vsliberal New left vsliberal Old left vsliberal New left vsliberal right

right

right

right

b

se.

b

se

b

se.

b

se.

\begin{tabular}{|c|c|c|c|c|c|c|c|c|}
\hline 989 & 0.195 & $(0.231)$ & 0.354 & $(0.255)$ & 0.216 & $(0.237)$ & 0.394 & $(0.262)$ \\
\hline 994 & -0.311 & $(0.264)$ & $0.494^{*}$ & $(0.291)$ & -0.313 & $(0.265)$ & $0.494^{*}$ & (0.292) \\
\hline 998 & $-0.622^{* *}$ & $(0.297)$ & -0.188 & $(0.330)$ & $-0.642^{\star \star}$ & (0.299) & -0.221 & $.334)$ \\
\hline 02 & -0.429 & $(0.333)$ & 0.284 & $(0.372)$ & -0.476 & $(0.342)$ & 0.223 & 0.385) \\
\hline 06 & -0.264 & $(0.403)$ & $-1.181^{* * *}$ & $(0.452)$ & -0.349 & $(0.423)$ & $-1.295^{\star * *}$ & $(0.481)$ \\
\hline ge & -0.002 & $(0.002)$ & $-0.024^{* * *}$ & $(0.003)$ & -0.002 & $(0.002)$ & $-0.024^{* * *}$ & $(0.003)$ \\
\hline ender (male = ref.) & $-0.131^{*}$ & $(0.068)$ & -0.010 & $(0.076)$ & $-0.131^{*}$ & $(0.068)$ & -0.010 & (0. \\
\hline \multicolumn{9}{|c|}{ Social class (manual class $=$ ref.) } \\
\hline igh technocrats & $-2.232^{* * *}$ & $(0.242)$ & $-1.783^{* * *}$ & $(0.283)$ & $-2.255^{* * *}$ & $(0.252)$ & -1.8 & $(0.2$ \\
\hline $\begin{array}{l}\text { igh social-cultural } \\
\text { ecialists }\end{array}$ & -0.708 & $(0.526)$ & -0.599 & $(0.540)$ & -0.775 & $(0.534)$ & -0.6 & $(0.552)$ \\
\hline w technocrats & $-1.389 * * *$ & $(0.2$ & $-0.883^{* * *}$ & $(0.240)$ & $-1.444^{* * *}$ & $(0.219)$ & $-0.883^{* * *}$ & $(0.2$ \\
\hline w social-cultural & $-0.916^{* * *}$ & $(0.247)$ & -0.126 & $(0.267)$ & $-0.893^{* * *}$ & $(0.275)$ & -0.170 & $(0.2$ \\
\hline $\begin{array}{l}\text { utine non- } \\
\text { anual }\end{array}$ & $-1.317^{* * *}$ & $(0.175)$ & $-0.912^{* \star *}$ & $(0.204)$ & $-1.384^{* * *}$ & $(0.194)$ & $-0.968^{* * *}$ & $(0.2$ \\
\hline employed & $-2.506^{* * *}$ & $(0.223)$ & $930 * * *$ & $(0.2 \varepsilon$ & $-2.498^{* * *}$ & $(0.242)$ & $1.924^{* * *}$ & (0.3 \\
\hline
\end{tabular}

Trend

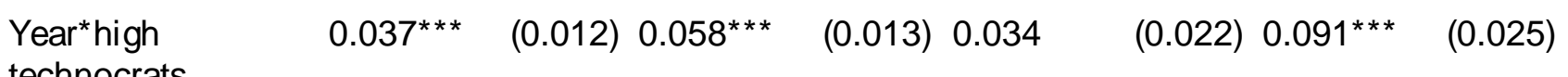
technocrats

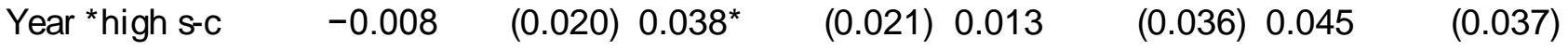

specialists

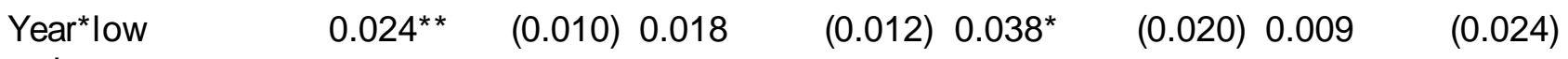

technocrats

$\begin{array}{lllllllll}\text { Year*low s-c } & 0.032^{* *} & (0.013) & 0.021 & (0.014) & 0.030 & (0.024) & 0.032 & (0.026)\end{array}$

specialists

Year*routine non- $0.021^{* *} \quad(0.009) 0.024^{* *} \quad(0.011) 0.033^{*} \quad(0.017) 0.035^{*} \quad(0.020)$ manual

Year*self-employed $0.026^{* *} \quad(0.012) 0.033^{* *} \quad(0.015) 0.023 \quad(0.023) 0.030 \quad(0.029)$

Bottom-up

Education in years $-0.162^{* * *}(0.022)-0.029 \quad(0.024)-0.163^{* * *}(0.022)-0.031 \quad(0.024)$

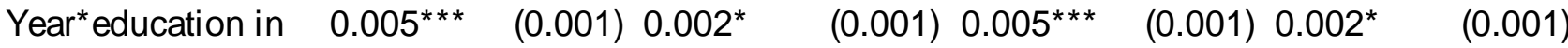
years

Economic $\quad-0.446^{* * *}(0.036)-0.398^{* * *}(0.042)-0.446^{* * *}(0.036)-0.399^{* * *}(0.042)$ conservatism

Year*economic $\quad-0.013^{* * *}(0.002)-0.010^{* * *}(0.002)-0.013^{* * *}(0.002)-0.010^{* * *}(0.002)$ conservatism

Top-down

GreenLeft merger since 1989

1989*high

$0.138 \quad(0.471)-0.854^{*} \quad(0.515)$

technocrats

1989*high s-c

$\begin{array}{lll}-0.570 \quad(0.811) & -0.157 \quad(0.807)\end{array}$

specialists

1989*low

$\begin{array}{llll}-0.364 & (0.452) & 0.257 & (0.526)\end{array}$ 
Model 3

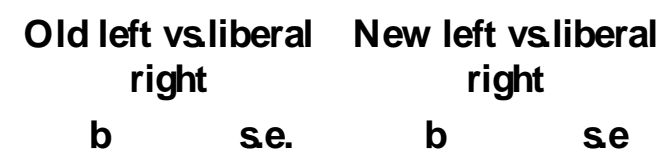

technocrats

$1989^{*}$ low s-c

specialists

1989*routine non-

manual

1989* ${ }^{*}$ elf-employed

$\mathrm{Df}$

Deviance

56

12617.7
Model 4

Old left vsliberal New left vsliberal right right

b se.

b

se.

68

12607.4

${ }^{*} p<.1^{* *} p<.05^{* * *} p<.01 ; N=8,023$

(p.236) (p.237) class both the main-effects as well as the linear trends are lower when we control for education; in other words: class voting is partially due to educational differences, and the differences in voting between the 'new' service classes and the working class are declining because the effect of education changed over time.

Model 3 (Table 9.3b) includes the voters' economic conservatism. We expected that we could interpret class voting differences by accounting for the fact that some classes are economically more conservative than others. We allow the effect of economic conservatism to change linearly over time. With the exception of the lower social-cultural specialists and the lower technocrats, neither with respect to voting old left, nor with respect to voting new left, can economic ideology interpret the linear trend-effects for class voting. We therefore can only find very modest support for hypothesis $2 b$. Interestingly, we notice an increase in the impact of economic conservatism. In 1971 the impact of economic conservatism on voting old left is -0.446 and this amounts to $-0.901(-0.446+(35$ * -0.013 ) in 2006: that is, for each step up on the economic conservatism scale, one is 1.56 times less likely to vote old left in 1971 and 2.46 times less likely in 2006. Also, with respect to voting new left versus liberal right, we find that economic conservatism is increasingly relevant to predicting party choice.

In model 4 we test the top-down interpretation using the merging of the minor left-wing parties into the Green Party in 1989. To test whether the association between class and vote for old and new left versus liberal parties shows an abrupt change after the 1989 election when GreenLeft came into existence, we include interactions between class categories and a dummy indicating the 1989 merger. The estimates reveal that in general this merging had no influence on class effects. We find only that from 1989 onwards the higher technocrats are less likely to vote for new left parties compared to the working class. We do not find that the odds of supporting new left parties for the social-cultural specialists increase after the formation of GreenLeft. Hence, we have to reject hypothesis 6.

Next we test hypothesis $3 \mathrm{~b}$ stating that the decline of the association between class and party choice becomes less strong when we take the ideological positions of parties into account. We look at the changes in the positions of parties between 1971 and 2002 with respect to social-economic issues (Figure 9.7a) and conservative versus progressive issues (Figure 9.7b). Figure 9.7a reveals a process of convergence between the major party groups in the Netherlands with respect to social-economic issues until 1994. Figures $9.5 \mathrm{a}$ and $9.5 \mathrm{~b}$ suggest convergence in class voting in this period as well. Figure $9.7 \mathrm{~b}$ clearly shows that the new left parties are the most progressive in the Dutch party system, and that the liberals are most conservative. The figure suggests ideological convergence between parties with respect to (p.238) 


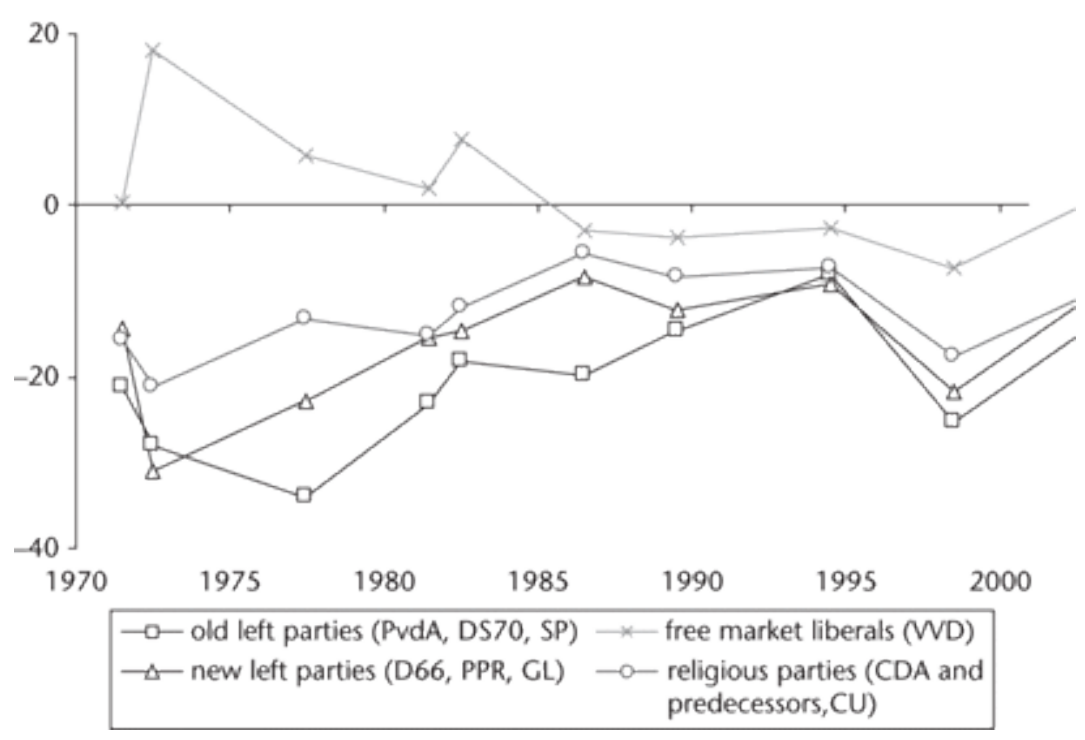

Figure 9.7a. Social-economic left-right positions of party groups in the Netherlands (1971-2002).

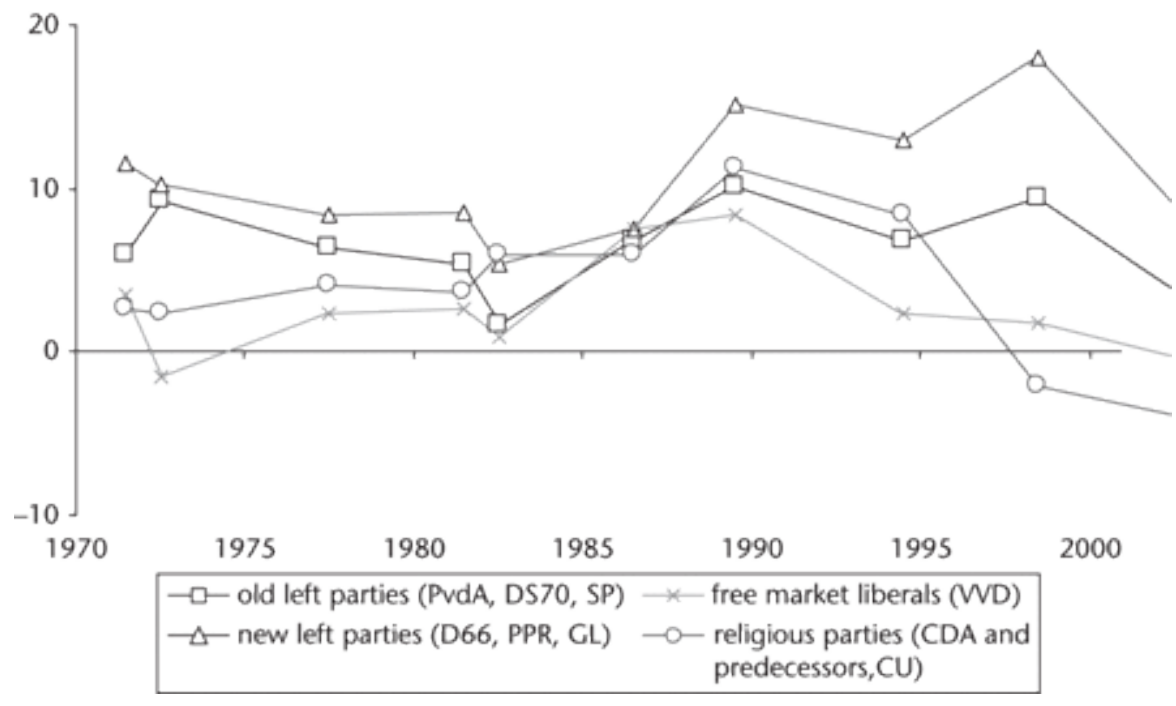

Figure 9.7b. Conservative versus progressive positions of party groups in the Netherlands (1971-2002).

Source: Comparative Manifesto Data $(2001,2006)$, own calculations.

(p.239) conservatism versus progressivism until 1986, but later we observe divergence on conservative versus progressive policy issues. In this case the relation with class-based voting as reported in Figures $\underline{9.6 \mathrm{a}}$ and $\underline{9.6 \mathrm{~b}}$ is less obvious.

To test to what extent party positions account for trends in class voting we again applied conditional logistic regression analysis, but we only report the main findings (cf. lansen, De Graaf, and Need 2011 for details). The conclusions are first of all that after accounting for all individual-specific variables in the model, the traditional economic left-right position of parties - and not their position on the cultural dimension - has a significant impact on vote choice between the four major party groups in the Netherlands between 1971 and 2002. This implies that the more right-wing the parties the more likely they will attract a vote. Second, it is rather surprising that the extent to which voters favour parties with economically right-wing policies does not seem to vary between the manual class and other classes (these models include economic conservatism at the individual level). Only low-grade social-cultural specialists tend to vote for parties that are economically left-wing. Apparently, changing party positions on the economic dimension are not responsible for the decline in class voting (hypothesis $3 b$ ).

Regarding the cultural dimension however, we find that manual workers tend to favour conservative 
parties, whereas other classes_again especially the low-grade social-cultural specialists_-prefer progressive parties. Although this clearly implies a top-down effect-namely that political choice matters, we did not find strong evidence that changes in the cultural positions of parties are able to account for the decline in class voting. Finally, there was no support for the claim that inclusion of party positions interprets the association between economic conservatism and party vote (hypothesis $4 b)^{8}$

\section{Conclusions}

The association between church membership and vote declines in the period 1971-2006 and most strongly before 1986. Especially for Catholics and Calvinists we observe convergence in voting behaviour compared to non-member voters. The blurring of the political boundaries between the Catholics and Calvinists with non-members is largely explained by declining church attendance. Declining church attendance, as an indicator of religious disintegration, suggests that people adhere less to the conservative norms and values preached in churches. In general, for all denominations and for Catholics in (p.240) particular, the association between church membership and attending church weakened between 1971 and 2006. The difference in church attendance between liberal Protestants and the non-members was al ready relatively small in the 1970s. Therefore, the initial decline in the association between being a Protestant and voting along confessional lines is weak. Indeed, accounting for religious disintegration produces an increase of religious voting among Protestants and people with 'other' religious affiliations.

We concluded that in addition to the linear trends the merging of religious parties into the CDA reduced the level of religious voting (see also De Graaf et al. 2001). The CDA merger seems to be particularly responsible for a decline in confessional voting among Calvinists and Protestants. We also found that the political merger of two minor Protestant parties into the ChristianUnion reduced the level of religious voting from the 2002 elections onwards. Interestingly, the party mergers not only had an independent effect on the strength of the religion-vote association, but the mergers mattered even after the linear trend is fully accounted for by the changing church attendance-vote relationship. Consistent with the political choice argument, we conclude that political interruptions are important influences on the process of religious dealignment.

We have shown that traditionalist party positions increase religious voting despite the weakening of religious integration and the restructuring of the party system. Since the decline in religious-based voting was already accounted for by the declining effect of church attendance, party positions cannot further interpret this decline. Another important conclusion is that after 1982 traditional values become more salient again in the party programmes of religious parties, which might imply that convergence of party programmes is less likely in PR systems. Decisions to move towards the centre are likely to be influenced by a concern about the flanks.

In this chapter we have described the evolution of political parties in the Netherlands. However, it is not only political parties that change over time but the cleavage structure as well. Besides changes in religion and church attendance, the class structure al so evolves. We find that the rise of a 'new' class of social-cultural specialists is important for understanding changes in the class-vote relationship. The higher and lower technocrats are clearly not only more right-wing, but the higher and lower socialcultural specialists have also developed strong preferences for new left parties, suggesting a process of realignment. Overall, the distinction between the manual class and other more traditional classes becomes less relevant for left-wing voting, which also implicates a process of class dealignment. We could not interpret these blurring effects nor the realignment of the social-cultural specialists by including voters' economic ideology and the merging of left-wing parties. The salience of cultural conservatism presumably reflects the popularity of the party of Pim Fortuyn and later Wilder's PVV.

(p.241) An unexpected finding with respect to left-wing voting was that the association between individual economic conservatism and left-wing voting increased, although only slightly, over time. This is surprising if one considers that an increasing number of non-economic topics are included in 
the political discussion, and this would make economic ideology less relevant. As mentioned earlier, the exact formulation and coding of the question about 'income differences' is slightly different in some pre-1989 surveys, and in particular in 1971 and 1972. However, we have no reason to assume these differences are responsible for the increasing effect of economic ideology on voting. Also, when we investigate shorter time trends (i.e. from 1981 or 1982 onwards), we find similar results with respect to the over-time effect of economic conservatism.

One explanation for this increasing association could be related to our finding that the ideological differences about income inequality are diminishing between the working class on the one hand and high technocrats and low social-cultural specialists on the other. Initially, the decline of class voting and the increasing importance of economic ideology would suggest a puzzle. But when we also consider the finding that the differences in left-wing voting between labourers and higher technocrats have decreased, and in the case of the low social-cultural specialist even reversed, it is plausible that economic ideology has become increasingly important for classes other than the manual class.

In addition to the old left versus free-market right voting contrast we also investigated the odds of voting for new left parties versus the free-market right. The analyses confirmed our expectation that the class of social-cultural specialists vote for new left parties. Interestingly, a lower level of education is decreasingly associated with voting left-wing, whereas new left parties are increasingly chosen by voters with higher education. A cultural or cognitive explanation for the decline in class voting seems to apply: education has the largest impact on class-effects with respect to voting old left versus liberal right. Especially for the sub-classes within the service class both the level and decline of the class effects are somewhat lower when we control for education. But after accounting for changes in the effect of educational differences and the blurring of ideological boundaries, the decline of class voting largely persists. However, we cannot test whether the inclusion of a 'left-libertarian' cultural progressive ideology would interpret class differences in voting new left.

We tested whether, after accounting for social changes, political choices offered to voters have an additional effect on the class-vote relationship. Despite covering more elections after 1989 and using a more differentiated class schema than De Graaf et al. (2001), we reached similar conclusions about the top-down effect of the GreenLeft merger: there is no evidence that the downward trends in class voting were influenced by this political merger. Using conditional logistic regression we conclude that even though political (p.242) parties seem to converge on the traditional left-right dimension, and diverge on 'new' political issues we were not able to explain trends in class voting by accounting for these political developments.

It is difficult to decide whether the bottom-up or top-down approach is more successful in explaining the associations between cleavages and voting behaviour. Both seem relevant and they are of course related. With regard to religious-based voting, we find strong evidence that the bottom-up explanation is successful. The inclusion of religiosity (as measured by church attendance) interpreted the decline in religious-based voting.

Finally, what can we conclude about the relative importance of class and religion? In his famous fourcountry comparison Lijphart found that where class, religion, and language were all present as competing bases, religion turns out to be victorious, language is a strong runner-up, and class finishes as a distinct third (1979: 452). Although there has been a strong decline in religious-based voting in the Netherlands, religion is still much more important than class for understanding voting behaviour. However, if one takes into account the evolution of class divisions, there is clear evidence of class realignment, especially regarding the support of new left political parties.

\section{Notes:}

(1) Of course, Lipset already suggested that the working class is perhaps ideologically left-wing on the basis of socio-economic issues but not with regard to cultural issues (Lipset 1959). From this perspective, the association between class and vote is declining because working-class conservatism is 
increasingly relevant to party choice (e.g. Van der Waal, Achterberg, and Houtman, 2007). However, in this study we cannot test to what extent cultural conservative ideology accounts for the decline of class voting because we lack a directly comparable measure of cultural conservatism (see also n. 6).

(2) We would like to thank Hans Schmeets, bs Beckersand, and Anton Kantebeen of the Central Bureau of Statistics in Heerlen for their hospitality and cooperation which made it possible to use the original occupational codes of the National Eection Surveys in order to create a detailed class schema for all surveys covering the period 1971-2006, with the exception of the 2003 survey.

(3) Before 1989 the exact formulation of this question was slightly different in each year. In the 1971 and 1972 surveys three response categories were used. We tried several recoding procedures to make the items comparable and all resulted in similar results. We recoded the 1971 and 1972 version into the seven-point version by giving the lowest category a score of 0 , the middle category a score of 3 and the highest category a score of 6 .

(4) For the 2002 elections the ChristianUnion is included in calculating the mean value of the religious party group. The CU only modestly ( 0.2 vs. 0.98$)$ affects the weighted value of the combined scores because it attracted just 2.54 per cent of the votes compared to the 27.93 per cent that went to the CDA.

(드) Because the CMP data only includes so-called 'significant' parties, not all parties in Dutch post-war electoral history are covered in the CMP dataset. Therefore, it must be noted that the Dutch Communist Party, Pacifist Socialist Party, and Evangelical People's Party are not covered in the CMP data thus not included in calculating the old left or new left mean scores. On the liberal right-wing side this al so applies to the Farmers Party and Middle Class Party.

(6) In order to check whether church attendance is a good choice as a proxy for cultural conservatism, we analysed the Dutch SOCON data from 1979-2005. These surveys contain vote intention, church attendance, and a validated scale for cultural conservatism. The results revealed that al though church attendance explains more variance, there is no difference in the extent to which ideology or church attendance can explain the trend in religious voting.

(7) A logistic regression of voting LPF in 2002 controlled for age, gender, education, and church attendance $(\mathrm{N}=1556)$ shows no significant $(\mathrm{p}\langle 0.1)$ differences between denominations. With the non-members as the reference group, the parameter estimates (b, se) are: Catholics $(0.25,0.23)$, Protestants $(-0.22,0.33)$ Calvinists $(-0.37,0.48)$, other religion $(0.05,0.46)$. Church attendance has a significant negative effect $(-0.345,0.08)$. People who attend church more often were less likely to cast a vote for the LPF in 2002.

(8) To be able to compare the results to the other chapters it is important to note that the conclusions about the impact of party positions do not change when using the traditional class schema without distinguishing the social-cultural specialists. 